\title{
1 Nitrogen and Sulfur deposition over a region in SW Europe based on a regional
} 2 atmospheric chemical transport model

3 Oliveira, M.A. ${ }^{a^{*}}$; Tomlinson, S.J. ${ }^{\text {}}$; Carnell, E.J. ${ }^{\text {c }}$; Dore, A.J. ${ }^{\text {c }}$; Serrano, H.C. ${ }^{a} ;$ Vieno, $4 \quad$ M. $^{\text {c }}$; Cordovil, C.M.d.S. ${ }^{\text {d }}$ Dragosits, U. ${ }^{c}$; Sutton, M.A. ${ }^{c}$; Branquinho, C. ${ }^{\text {a }}$ Pinho, P. ${ }^{\text {a }}$

$5{ }^{\mathrm{a}}$ Centre for Ecology, Evolution and Environmental Changes, Faculdade de Ciências, 6 Universidade de Lisboa, Edifício C2, Piso 5, Sala 2.5.46 Campo Grande, 1749-016

7 Lisboa, Portugal

$8{ }^{\mathrm{b}}$ UKCEH/UK Centre for Ecology \& Hydrology, Lancaster Environment Centre, 9 Library Avenue, Lancaster, UK, LA1 4AP

$10{ }^{\mathrm{c}}$ UKCEH/UK Centre for Ecology \& Hydrology, Bush Estate, Penicuik, Midlothian, 11 UK, EH26 0QB

12 d Universidade de Lisboa, Instituto Superior de Agronomia, LEAF, Tapada da Ajuda, 13 1349-017 Lisboa, Portugal

\section{Abstract}

Air quality affects both ecosystems and human health. To assess the effects of air pollution, spatially explicit information of pollutants is needed. Atmospheric chemistry transport models are the best option to estimate concentrations and deposition of pollutants from local to regional scales. However, concentration and deposition maps derived from available regional and global models are typically given at spatial resolutions of 10 to $50 \mathrm{~km}$ and do not contain information at sufficiently high spatial resolution (i.e. $\leq 5 \mathrm{~km} \times 5 \mathrm{~km}$ ) to identify risks and to develop solutions to protect ecosystems and human health. Here we provide deposition and concentrations of nitrogen $(\mathrm{N})$ and sulfur $(\mathrm{S})$ at a $5 \mathrm{~km} \times 5 \mathrm{~km}$ resolution for the western Iberian Peninsula. The new maps are a major improvement over existing information due to the higher spatial resolution. Comparisons with measurements indicate that all maps for $\mathrm{N}$ compounds are fit for purpose.

Nitrogen deposition in $\mathrm{W}$ Iberia ranged from 3 to $38.6 \mathrm{~kg} \mathrm{~N} \cdot \mathrm{ha}^{-1} \cdot$ year $^{-1}$, averaging $~ 8.2$ $\mathrm{kg} \mathrm{N} \cdot \mathrm{ha}^{-1} \cdot$ year $^{-1}$ with a higher contribution from reduced $\mathrm{N}$ forms $(62 \%)$. Deposition of oxidized forms mainly prevailed in urban and industrial areas and in coastal locations. The contribution of wet deposition was slightly higher (55\%) than dry deposition and more important in the North, following the pattern of precipitation. Dry deposition is higher closer to emission sources.

33 Due to their high spatial resolution, these maps can be used for policy development to support ecosystem protection, through the identification of areas at greater risk due to high $\mathrm{N}$ deposition. National policy efforts to reduce $\mathrm{N}$ pollution must, foremost, target ammonia $\left(\mathrm{NH}_{3}\right)$ emissions in rural areas and oxidized nitrogen $\left(\mathrm{NO}_{\mathrm{x}}\right)$ emissions in urban and industrialized areas. 
Keywords: FRAME; high resolution; eutrophication; acidification; Iberian Peninsula; Mediterranean

\section{Introduction}

Once released from sources into the atmosphere as gases or particulates, air pollutants impact human health and biota. Once deposited to ecosystems, pollutants also impact ecosystem biodiversity (Nowak et al., 2015). Some nitrogen (N) pollutants and sulfur (S) are respiratory tract irritants causing detrimental health effects (Chen et al., 2007). Moreover, they contribute to the generation of acid rain which is also known to damage historical buildings (Yates et al., 1988). Regarding impacts on ecosystems, excess atmospheric $\mathrm{N}$ and $\mathrm{S}$ cause eutrophication, acidification, nutritional imbalances and a decrease in species richness (e.g. Bobbink \& Hettelingh, 2011; Greaver et al., 2012). Under a "business as usual" future scenario, these effects will be further increased with rising temperatures due to climate change, and with the intensification and extension of agricultural land due to a large increase in population, which will in turn generate an increase in ammonia emissions and cascading effects related with the $\mathrm{N}$ cycle (Erisman et al., 2011; Skjøth and Geels, 2013).

Due to the observed effects of acid rain to ecosystems and cultural heritage, the Convention on Long-Range Transboundary Air Pollution (CLRTAP) was established in 1979 (Reis et al., 2012). Since then, the CLRTAP has been extended by several protocols, such as the Gothenburg Protocol, which has promoted a close collaboration between science and policy-makers in the development of air pollution abatement strategies based on a multi-pollutant and multi-effect approach (Reis et al., 2012), including effects on human health. The recent revision of the Gothenburg Protocol resulted in legislation (Directive EU 2016/2284 known as the NEC Directive), which set national emission ceilings and aims for a reduction of atmospheric emissions of pollutants, including $\mathrm{N}$ and S, with targets for 2020 to 2029.

High resolution deposition and concentration maps are important datasets to support air quality policy development, especially to meet the Habitats Directive (Council Directive 92/43/EEC) and the NEC Directive, to protect biodiversity and ecosystems by urging Member States to monitor the impacts of concentration and deposition of acidifying, eutrophying and ozone air pollution on ecosystems and to target emission reductions in locations where critical thresholds are exceeded. Concentrations of sulfur dioxide $\left(\mathrm{SO}_{2}\right)$, nitrogen oxides $\left(\mathrm{NO}_{\mathrm{x}}\right)$ and ammonia $\left(\mathrm{NH}_{3}\right)$ rapidly change with increasing distance from emission sources (cf. Sutton et al., 1998; Cape et al., 2004; Dragosits et al., 2002; 2006; Pinho et al., 2011; Vogt et al., 2013; Barros et al., 2015; Moran et al., 2016). For this reason, high resolution maps of deposition are important for assessing the threat to sensitive species and ecosystems with high pollution loads (through quantification of critical levels exceedance) (cf. Pinho et al., 2018). This approach is currently being applied in other countries in Europe (e.g. Ellermann et al., 2018), and, to be successful, does require high-resolution concentration data. Nationwide in Portugal, air pollution monitoring is based on limited numbers of strategically placed measurement stations with limited spatial resolution. In this context, models are critical, complementing the information provided by measurement stations and offering high resolution maps of pollutant concentration and deposition patterns. 
The spatial resolution of regional/global models is typically rather coarse $(\sim 10 \mathrm{~km} \times 10 \mathrm{~km}$ to $50 \mathrm{~km} \times 50 \mathrm{~km})$ and is insufficient to for identifying areas at risk, in which total deposition surpasses critical loads, as pollutant concentrations vary significantly at scales under $10 \mathrm{~km}$. The EMEP/MSC-W (European Monitoring and Evaluation Programme/Meteorological Synthesizing Center-West) transport model simulates atmospheric chemistry on a European scale. This is a policy-driven programme under the CLRTAP for international co-operation to solve transboundary air pollution problems (Simpson et al., 2012). In addition, and within Europe, regional models have also been widely used in the past 20 years, such as in the United Kingdom (UK) (Singles et al., 1998; ApSimon et al., 1994; Smith et al., 2000; Fournier et al., 2004; Dore et al., 2007; 2012; 2015), which has led to high resolution (1 km×1 km and $5 \mathrm{~km} \times 5 \mathrm{~km}$ ) maps of $\mathrm{N}$ deposition (e.g. Dore et al., 2009; 2012). More recently, regional air pollution models have also been applied in Spain with a $10 \mathrm{~km} \times 10 \mathrm{~km}$ grid resolution (García-Gómez et al., 2014) and Poland with a $5 \mathrm{~km} \times 5 \mathrm{~km}$ grid resolution (Kryza et al., 2009; 2013). These models have shown promising results, with higher spatial resolution, when compared to the complex large-scale (and lower resolution) EMEP transport model. With respect to mainland Portugal, modelling of the spatial distribution of air concentrations of the main atmospheric pollutants has been undertaken with a $5 \mathrm{~km} \times 5 \mathrm{~km}$ and $9 \mathrm{~km} \times 9 \mathrm{~km}$ resolution (e.g. Monteiro et al., 2015; Moran et al., 2016). However, high-resolution maps of nitrogen deposition are yet to be produced and evaluated.

Substantial knowledge exists in modelling concentration and deposition of pollutants in Atlantic and continental biogeographical regions (i.e. northern and central Europe), where most pollutants are deposited as wet deposition. However, there is comparatively less knowledge in modelling and critically evaluating model outputs for drylands. In these areas, such as Portugal and Spain with a Mediterranean climate, the dry season extends for several months, and thus dry deposition is regarded as dominant (Bytnerowicz \& Fenn, 1996; García-Gómez et al., 2018). The need to increase knowledge regarding $\mathrm{N}$ and $\mathrm{S}$ deposition is particularly important for Portugal, given that it ranks amongst the top countries on the European Union with high landscape diversity, characterized by the significant presence of mountainous or hilly areas, and the high complexity of its landscape structure, characterized by diverse types of landcover (Palmieri et al., 2011). This is relevant in what concerns air pollution modelling, as wet deposition is strongly related with precipitation, which is strongly related with changes in topography; and dry deposition depends, in part, of the capability of the surface to capture or absorb the species (Hertel at al., 2011), differentiated by landcover.

With the aim to provide the tools to fulfil the requirements of the NEC and Habitat Directives, the specific objective of this paper was to map the concentration and deposition of $\mathrm{N}$ and S-based pollutants in W Iberia. Taking into consideration that the directive focuses on targeted emission reductions based on threshold exceedances and their impacts on ecosystems, which improve by increasing model resolution, mapping was carried out at a high spatial resolution $(5 \mathrm{~km} \times 5 \mathrm{~km})$, compared with existing available information (i.e. EMEP with a $10 \mathrm{~km} \times 10 \mathrm{~km}$ resolution). The increase in model resolution will contribute to the identification of pollution hotspots and of ecosystems at risk of eutrophication/acidification. The model used in this study was 
FRAME (Fine Resolution Atmospheric Multi-pollutant Exchange, version number 915-0), which has been successfully applied in the UK and Poland (Dore et al., 2009; 2012; Kryza et al., 2009; 2013) as well as for the North China Plain (Zhang et al., 2011). Model results were evaluated using concentration and wet deposition data measured in monitoring stations in W Iberia and compared with EMEP model results.

The output of this work, namely $\mathrm{N}$ deposition maps, is critical in the identification of areas where critical thresholds (critical loads and levels) are being exceeded, which is crucial information for policymakers to develop measure aiming to protect sensitive ecosystems and human health. Moreover, it represents a steppingstone to further increase the resolution of nation-wide $\mathrm{N}$ and $\mathrm{S}$ deposition maps in future.

\section{Methods}

\subsection{Study Area}

The modelling domain covers a $660 \mathrm{~km} \times 850 \mathrm{~km}$ area in SW Europe, centred on Portugal (Figure 1A) and at a $5 \mathrm{~km} \times 5 \mathrm{~km}$ grid resolution. The domain extends towards the west of Portugal to include emissions from major international shipping routes. It also extends towards the east to include measurement stations used in model evaluation (further described in Section 2.2.2). Due to large variations in latitude $\left(36^{\circ}-44^{\circ}\right)$, continentality (from maritime to continental) and elevation ( 0 to $>2000 \mathrm{~m}$ ) within the study area, there is a wide variety of climatic conditions, which can be classified into several morphogenetic regions: humid mid-latitude, semi-arid and dry-continental (Benito-Calvo et al., 2009; Andrade and Corte-Real, 2015). Precipitation reaches maximum values in the northern part of the study area (> $2100 \mathrm{~mm} \cdot$ year $\left.^{-1}\right)$, gradually decreasing towards the south until reaching minimum values of $\sim 250 \mathrm{~mm} \cdot$ year $^{-1}$ (Figure 1B).

Wind conditions in the study area are mostly controlled by the larger river valleys, plateaus and coastline irregularities of the Iberian Peninsula, which promote diversity in the wind behaviour, but showing an overall strong influence of the Atlantic Ocean (Lorente- Plazas et al., 2015). Average annual temperatures range from $-3^{\circ} \mathrm{C}$ in the mountainous regions in the northern part of the study area to $12^{\circ} \mathrm{C}$ in the coastal plains further south (cf. Ninyerola et al., 2005).

Figure 1: Location of the study area. (A) Location of the domain used in the simulations for SW Europe; (B) Total precipitation within the domain in 2015 (from the EMEP MSC-W); (C) Wind rose considered as representative for the domain calculated by the Weather Research Forecast (WRF) model at the sampling locations identified in (B)

\subsection{Model Description}

FRAME is a Lagrangian atmospheric transport model employing annually averaged statistical meteorology to predict annual mean deposition of reduced nitrogen $\left(\mathrm{NH}_{\mathrm{x}}\right)$, oxidised sulfur $\left(\mathrm{SO}_{\mathrm{x}}\right)$ and oxidised nitrogen $\left(\mathrm{NO}_{\mathrm{y}}\right)$ across a gridded domain (Vieno, 2006). FRAME uses a multi-layer scheme to describe vertical diffusion explicitly, based 
on anthropogenic emissions (Singles et al., 1998), with the main atmospheric processes occurring in a column of air extending from ground level to $2500 \mathrm{~m}$, in 33 vertical layers (with steps at 2, 4, 6, 10, 25, 50, 75, 100, 150, $200 \mathrm{~m}$, and thereafter in $100 \mathrm{~m}$ steps) (Singles et al., 1998; Dore et al., 2009). There are four main processes that occur within the air column: emission, diffusion, chemistry and deposition (Vieno, 2006). Furthermore, the atmospheric transport and chemistry of pollutants at a European scale are also calculated (50 $\mathrm{km}$ resolution) to establish boundary conditions at the domain edges. Boundary concentrations are determined with a FRAME-Europe simulation at a $50 \mathrm{~km}$ resolution over the whole of Europe. A total of 8 simulations with a 45 -degree directional resolution are run to generate air concentrations at the domain boundary to initialize concentrations for the $5 \mathrm{~km}$ simulation (using a $1^{\circ}$ directional resolution).

Straight-line wind trajectories are advected from the edge of the model domain, in relation to twenty-four wind direction sectors and the results are combined statistically, suitably weighted by the frequency of winds from each direction (Singles et al., 1998; Dore et al., 2009; Kryza et al., 2013). The FRAME model operates on annual average results, providing information on total annual deposition and average concentrations of $\mathrm{S}$ and $\mathrm{N}$ compounds (Kryza et al., 2013). It includes aqueous phase and gas phase oxidation reactions for sulfur and oxides of nitrogen. The FRAME model does not include photochemistry and only includes secondary inorganic aerosols. Ammonium sulfate aerosol is formed by a one-way reaction between ammonia and sulfuric acid. The equilibrium between gas phase ammonia and nitric acid and particulate ammonium nitrate is included. A large nitrate aerosol is included which represents the process of deposition of nitric acid onto sea salt and dust particles. Dry deposition is based on vegetation dependent velocities for each chemical species derived from the dry deposition model, whereas wet deposition is calculated using scavenging coefficients and a constant drizzle approach, based on precipitation rates (Kryza et al., 2013). The wet deposition flux to the surface is the sum of wet removal of pollutants from the air, assuming the scavenged material comes down as precipitation (Kryza et al., 2013). No differentiation is made between in-cloud and below-cloud processes, with an average value of the scavenging ratio used to represent both processes (Fournier, 2002). Different scavenging ratios (listed in Table S I of the supplementary materials), depending on the characteristics of the pollutant, are combined with the rainfall rates to produce scavenging coefficients (cf. Fournier, 2002). A detailed description of the FRAME model, including the chemical scheme, can be found in Singles et al. (1998), Fournier (2002), Fournier et al. (2004) and Vieno (2006).

The EMEP/MSC-W transport model is an Eulerian model which has been extensively used to simulate atmospheric chemistry in Europe, used for air pollution policy assessments, in support of the CLRTAP. The model domain covers all of Europe, and the model was built for describing long range transport of pollution on a horizontal $50 \mathrm{~km} \times 50 \mathrm{~km}$ grid (Simpson et al., 2012), but recently has been running at $0.1^{\circ} \times 0.1^{\circ}$ (approx. $10 \mathrm{~km}$ x $10 \mathrm{~km}$; Fagerli et al., 2017). The EMEP model uses 20 vertical levels with a surface layer of approximately 90 m (van Pul et al., 2009a; Simpson et al., 2012). The meteorological data to drive the EMEP MSC-E air quality model have been generated by the ECMWF-IFS weather forecast (most recent version Cycle 40r1) and are given at 3-hourly intervals (Simpson et al., 2012; Tsyro et al., 2018). Parameterization of wet deposition includes both in-cloud and sub-cloud scavenging of 
gases and particles (Simpson et al., 2012). Dry deposition is applied to 16 land use classes derived from the CORINE system in Europe (van Pul et al., 2009b; Simpson et al., 2012). The model requires gridded annual national emissions of $\mathrm{SO}_{2}, \mathrm{NO}_{\mathrm{x}}, \mathrm{NH}_{3}$, non-methane volatile organic compounds, carbon monoxide and particles subdivided into defined source sectors (Simpson et al., 2012). These emissions are then distributed vertically according to a default distribution based on source sectors (for further detail consult Simpson et al., 2012). Emissions are temporally distributed according to country, reflecting, for example, different energy-use patterns in different parts of Europe (Simpson et al., 2012). More information regarding the technical description of the EMEP MSC-W model can be found in Simpson et al. (2012) and recent changes in model code are further described in Simpson et al. (2017; 2018). In this work, deposition and concentration of $\mathrm{N}$ and S compounds were based on EMEP MSC-W model version rv4.17a, available from The Norwegian Meteorological Institute website (The Norwegian Meteorological Institute, 2018).

The FRAME model and the EMEP model are fundamentally different models. The FRAME model is based on statistically derived annually averaged meteorology. The EMEP model is a full 3D+time Eulerian photochemistry model (Simpson et. al. 2012) driven by hourly $3 \mathrm{D}$ meteorological data. FRAME advects an air column according to the annual mean wind speed and wind directions along straight-line trajectories with a one-degree angular resolution. Wet removal is calculated by a constant drizzle using scavenging coefficients with no differentiation between in-cloud and below cloud scavenging and it includes an orographic enhancement of washout (Fournier, 2002; van Pul et al., 2009b; Kryza et al., 2013). By contrast, EMEP calculations are performed at an hourly time scale and driven by real-time meteorology (Vieno et al., 2014). For dry deposition, FRAME calculates deposition velocities individually for five different land cover categories, whereas EMEP uses 16 (van Pul et al., 2009b). FRAME has a higher vertical resolution than EMEP, the first vertical layer reaching 1m, while for EMEP it approximately $90 \mathrm{~m}$. For further details refer to van Pul et al. (2009a; b) and Dore et al., (2015), where a comprehensive comparison between several air quality models, including FRAME and EMEP, can be found. Horizontal resolution used in this work also differs between models. The FRAME run was based on a $5 \mathrm{~km} \times 5 \mathrm{~km}$ grid and EMEP's on a $\sim 10 \mathrm{~km} \times 10 \mathrm{~km}$ grid.

\subsubsection{Inputs and conditions}

FRAME requires the following input data: (1) in-domain $\mathrm{NO}_{x}, \mathrm{NH}_{3}$ and $\mathrm{SO}_{\mathrm{x}}$ emissions, which can be provided separately as diffuse area-based emissions (DE) and large point source emissions (LPS); (2) wind-rose data containing wind frequency and speed; (3) precipitation; (4) land cover, and (5) boundary conditions containing $\mathrm{N}$ and $\mathrm{S}$ components from the surrounding European-scale domain.

Emissions were compiled from nationally estimated and reported values of anthropogenic emissions for 2015, provided by Agência Portuguesa do Ambiente (APA) to EMEP, supplied at $0.1^{\circ}$ gridded resolution (longitude and latitude). Emissions were disaggregated into smaller cells, the emission value per cell being divided by the number of new cells in the overlapping region, and reformatted to a $5 \mathrm{~km} \times 5 \mathrm{~km}$ resolution grid for the regional FRAME model domain. This included $\mathrm{NO}_{\mathrm{x}}, \mathrm{SO}_{\mathrm{x}}$ and 
$\mathrm{NH}_{3}$ emissions from Portugal, an area of Spain and international shipping made available by the Centre on Emission Inventories and Projections (EMEP/CEIP, 2018) and large point source (LPS) emissions from the E-PRTR (The European Pollutant Release and Transfer Register, 2018) database. Gridded emissions (GE) correspond to total emissions per grid cell, including both diffuse and large point emissions.

$\mathrm{NO}_{\mathrm{x}}, \mathrm{SO}_{\mathrm{x}}$ and $\mathrm{NH}_{3} \mathrm{GE}$, expressed as $\mathrm{Gg}$ per grid cell, from Spain, Portugal and international shipping, within the domain, are presented in Figure 2A-C (and are also provided separately for each relevant activity in the supplementary material, Figure $\mathrm{S} 1$ to Figure S 3). The highest $\mathrm{NO}_{\mathrm{x}}$ and $\mathrm{SO}_{\mathrm{x}}$ emissions correspond to large point sources, as can be seen in the strong contrast between confined maximum emissions and lower surrounding values (Figure $2 \mathrm{~A}$ and $\mathrm{C}$ ). This is especially true for $\mathrm{SO}_{\mathrm{x}}$, where the largest source of emissions $(\sim 45 \%)$ is combustion by power plants and industry (Figure $2 \mathrm{D}$ and more information available in Figure S 3 of the supplementary materials).

Figure 2: Gridded emissions (expressed as Gg by grid cell) from EMEP within the domain used in the simulations: (A) $\mathrm{NO}_{\mathrm{x}}$ emissions; (B) $\mathrm{NH}_{3}$ emissions; (C) $\mathrm{SO}_{2}$ emissions; (D) Emission totals per activity within the domain represented by $D$ and in the Portuguese part of the domain by PT

International shipping routes are visible in both the $\mathrm{NO}_{\mathrm{x}}$ and $\mathrm{SO}_{\mathrm{x}}$ emission maps, indicating an important contribution to $\mathrm{N}$ and $\mathrm{S}$ compounds in the western part of the domain (corresponding to $30 \%$ of total $\mathrm{NO}_{\mathrm{x}}$ emissions and $43 \%$ of total $\mathrm{SO}_{\mathrm{x}}$ emission within the domain).

In contrast, the spatial distribution of $\mathrm{NH}_{3}$ emissions indicates mostly diffuse sources related to agricultural crop and livestock production with minor contributions from industrial activities and relatively low-emission from LPS with livestock and industrial activities (Figure 2B and more information available in Figure S 2 of the supplementary materials).

289 Emission sectors are introduced into the model separately for increased vertical resolution. LPS data are allocated to a specific height (e.g. stack height from industries and power plants), and FRAME computes the plume rise after Hanna et al. (1982, in Vieno, 2006) using additional parameters, such as stack diameter, emissions' exit velocity and temperature (Vieno et al., 2010). Where stack parameters are not available, a set of default data are used by FRAME to determine the plume rise of large point sources. Furthermore, DE are evenly distributed within a range of vertical layers, according to the activity, using emission heights and values for plume rise from the literature (Frick \& Hoppel, 2000; IPCC 2006, 2006; Li et al., 2017) (more information available in Table $\mathrm{S}$ I of the supplementary materials).

However, a few issues arise when separating this information. E-PRTR emissions are determined using a bottom-up approach based on detailed information for individual emission sources (Winiwarter \& Schimak, 2005). GE are determined using a top-down approach by multiplying an emission factor with a parameter for each type of activity (e.g. energy consumption, production figures, distance driven etc.) at a larger 
(administrative) level, where statistical data are available (Winiwarter \& Schimak, 2005). Given these differences in their determination, emissions in both databases might not perfectly overlap. In most cases, LPS emissions are lower than the value in the underlying cell, which is to be expected given that GE incorporate both LPS and DE from every activity. However, due to differences in the methodology used in the determination of emissions, in some cases, emissions from LPS in the E-PRTR database are larger than the underlying cell in the GE dataset. In these cases, negative values result when subtracting LPS emissions from GE. To resolve this, the excess emission data from the LPS were taken from the individual surrounding eight grid cells in GE, as a proportion of each cell to the total of all eight.

The resulting DE were regridded to $5 \mathrm{~km}$ and re-projected to a Portuguese national datum (Datum Lisboa Hayford-Gauss) using R 3.4.3 (R Core Team, 2017) and proj4, raster and rgdal R packages (Urbanek, 2012; Hijmans, 2017; Bivand et al., 2018).

Precipitation data used in the simulations were based on the EMEP MSC-W model from 2015. These data were chosen for comparability purposes, to better evaluate differences in $\mathrm{N}$ and $\mathrm{S}$ concentration and deposition obtained from both models (EMEP and from 2015 with a $0.1^{\circ}$ resolution for Europe (Figure 1B) (Data from The Norwegian Meteorological Institute, 2018). EMEP precipitation was evaluated using official total annual precipitation data in Portugal (Instituto Português do Mar e da Atmosfera, 2017), showing a good overall correlation (normalized mean bias of 0.13 and a normalized root mean square error of 0.27 , corresponding to $152 \mathrm{~mm}$ ), with data being slightly overestimated especially for higher precipitation values.

The precipitation raster data were re-projected to the Portuguese national grid, regridded by bilinear interpolation and cropped to cover the same domain and resolution as the emissions, using the raster package (Hijmans, 2017) in R 3.4.3 (R Core Team, 2017).

Wind data were calculated by the Weather Research Forecast model (WRF, version 3.7.1) (www.wrf-model.org) (Skamarock et al., 2008). The WRF model setup used here included data assimilation (Newtonian nudging) of the numerical weather prediction (NWP) model, meteorological reanalysis from the US National Center for Environmental Prediction (NCEP)/National Center for Atmospheric Research (NCAR) and Global Forecast System final reanalysis (GFS-FNL) at a 1 degree resolution, every 6 hours (National Centers for Environmental Prediction/National Weather Service/NOAA/U.S. Department of Commerce, 2000).

WRF model evaluation has been performed for wind velocity and direction using eight World Meteorological Organization (WMO) observation sites included in the MIDAS dataset (Met Office, 2012), and within the model domain (Figures S 4 to S 12 and Tables S II and S III in the supplementary materials). In general, the WRF model adequately represents the range of wind speed and wind direction. The observation at specific sites is clearly influenced by local orography, such as the presence of river valleys which partly channel the wind, and which is not well represented at the resolution used in this work. The observations also include biases which affects model evaluation due to accuracy requirements of 1 knot or $10 \%$ for speed are within, and within $5^{\circ}$ for direction. 
The WRF simulation was run with a horizontal resolution of $50 \mathrm{~km}$. Output hourly data were extracted for five locations in Portugal (Figure 1B) at an altitude of $400 \mathrm{~m}$ above the friction layer and therefore representative of geostrophic flow and were taken as representative of the domain. Wind input data resulted from hourly wind velocity and direction in 2015 from 5 sampling points within the domain (Figure 1B). Hourly data were grouped into $15^{\circ}$ classes and wind direction frequency and mean harmonic wind speed were determined for each directional class. The resulting wind data used as input for the FRAME are represented in Figure 1C. The WRF data used here were originally generated for the EMEP4UK model (Vieno et al., 2016).

Habitat-specific deposition data are provided as $5 \mathrm{~km}$ grid average values for the following landcover types (Bealey \& Dore, 2017): arable, grassland, urban, forest and low-growing semi-natural vegetation. Mapping of land cover types required as model input was based on the Corine 2012 landcover data (European Union, 2017) using a correspondence table (available in the supplementary materials, Table S IV). Mapping and fractions of different land cover types within the domain are also represented in the supplementary materials (Figure S 13).

\subsubsection{Evaluation}

Model results were evaluated using mean concentrations from observations in background stations of: (1) the Portuguese Environmental Agency (Agência Portuguesa do Ambiente, 2017); (2) the airbase stations covering the Spanish part of the domain (European Environmental Agency, 2018); (3) EMEP monitoring stations (Norwegian Institute for Air Research, 2017). Medium, pollutants and units are listed in Table I and station locations are represented in Figure $3 \mathrm{~A}$ and B. As FRAME does not include photochemistry and only includes secondary inorganic aerosols, it is not possible to evaluate model performance for $\mathrm{O}_{3}$ (ozone) or PM2.5 (particulate matter with a diameter of less than 2.5 micrometers) concentrations.

Table I: Components used in the evaluation of model results

\begin{tabular}{|c|c|c|c|}
\hline Database & Medium & Pollutant & Units \\
\hline APA + Airbase & Air & $\mathrm{NO} ; \mathrm{SO}_{2}$ & $\mu \mathrm{g} \cdot \mathrm{m}^{-3}$ \\
\hline \multirow{3}{*}{ EMEP } & Air and aerosol & $\mathrm{NH}_{3}+\mathrm{NH}_{4}{ }^{+} ; \mathrm{NO}_{3}{ }^{-}+\mathrm{HNO}_{3}$ & $\mu \mathrm{g} \cdot \mathrm{m}^{-3}$ \\
\cline { 2 - 4 } & \multirow{2}{*}{ Precipitation } & $\mathrm{NO}_{3}{ }^{-} ; \mathrm{NH}_{4}{ }^{+}$ & $\mathrm{mg} \mathrm{N} \cdot \mathrm{L}^{-1}$ \\
\cline { 3 - 4 } & & $\mathrm{xSO}_{4}{ }^{-2}($ sea salt corrected $)$ & $\mathrm{mg} \mathrm{S} \cdot \mathrm{L}^{-1}$ \\
\hline
\end{tabular}

Only EMEP airbase and APA background stations in Portugal and Spain (within the domain), showing a data capture of $75 \%$ on an annual basis in 2015 , were used. Boxplot diagrams of the values for the different measured pollutants within the domain are represented in Figure 3C.

Figure 3: (A) Location of APA and airbase measurement stations (see text for explanation); (B) Location of EMEP measurement stations (see text for explanation); (C) Box-plot diagrams for average $\mathrm{N}$ and $\mathrm{S}$ compounds in 2015 
measured in the air and aerosol; (D) ) Box-plot diagrams average $\mathrm{N}$ and $\mathrm{S}$ compounds in 2015 measured in the precipitations

Following recommendations by Chang \& Hanna (2004, 2005), several statistical measures were used to evaluate model performance, comprising: fraction of predictions within a factor of two of observations (FAC2); relative mean bias or fractional bias as a ratio of $\mathrm{M} / \mathrm{O}\left(\mathrm{FB}_{\mathrm{M} / \mathrm{O}}\right)$ and the normalized mean square error (NMSE) (described in section 6 of the supplementary materials).

According to Chang \& Hanna (2004, 2005), a model performs adequately when $\mathrm{FAC} 2 \geq 50 \%, \mathrm{FB} \leq 30 \%$ (corresponding to $\mathrm{FB}_{\mathrm{M} / \mathrm{O}}$ between 0.7 and 1.3 ) and NMSE $\leq 1.5$ (representing a random scatter of about a factor of 2 or 3 of the mean). Furthermore, a model is considered as fit for purpose based on a comprehensive acceptance criterion of $50 \%$, meaning that at least $50 \%$ of performance criteria are met (cf. Hanna \& Chang, 2010). Statistical measures for the evaluation of model performance were determined for both FRAME and EMEP modelling results, within the domain.

\section{Results}

Scatter plots showing predictions against observations, separated by country, are shown in Figures 4 and 5. Performance criteria were determined using Portuguese stations only and all stations in the domain (Table II).

Figure 4: Scatter plots of the annual average modelled concentration with measurements from the monitoring network, PT represents stations in Portugal and $\mathrm{SP}$ in the rest of the domain (in Spain): (A) $\mathrm{NO}_{\mathrm{x}}$ in the air; $(\mathrm{B}) \mathrm{SO}_{2}$ in the air; (C) $\mathrm{NH}_{3}$ in the air and $\mathrm{NH}_{4}{ }^{+}$in aerosols; (D) $\mathrm{HNO}_{3}$ in the air and $\mathrm{NO}_{3}{ }^{-}$in aerosols. Full line represents $\mathrm{M}=\mathrm{O}$ and dashed line represents a factor of 2 used in the evaluation

Figure 5: Scatter plots of the annual average modelled concentrations in the precipitations with measurements from the monitoring network, PT represents stations in Portugal and SP in the rest of the domain (in Spain): (A) $\mathrm{NH}_{4}^{+}$; (B) $\mathrm{NO}_{3}{ }^{-}$ ; (C) $\mathrm{xSO}_{4}{ }^{-2}$. Full line represents $\mathrm{M}=\mathrm{O}$ and dashed line represents a factor of 2 used in the evaluation

Table II: Performance criteria (fraction of predictions within a factor of two of observations - FAC2, fractional bias in the ratio of $\overline{\mathrm{M}}$ to $\overline{\mathrm{O}}-\mathrm{FB}_{\mathrm{M} / \mathrm{O}}$ and normalized mean square error - NMSE).

\begin{tabular}{|c|c|c|c|c|c|c|c|c|c|}
\hline \multirow{2}{*}{ Medium } & \multirow{2}{*}{\multicolumn{2}{|c|}{ Pollutant }} & \multirow{2}{*}{$\mathrm{N}^{*}$} & \multicolumn{3}{|c|}{ FRAME } & \multicolumn{3}{|c|}{ EMEP } \\
\hline & & & & FAC2 & $\mathrm{FB}_{\mathrm{M} / \mathrm{O}}$ & NMSE & FAC2 & $\mathrm{FB}_{\mathrm{M} / \mathrm{O}}$ & NMSE \\
\hline \multirow{2}{*}{ Air } & \multirow{2}{*}{$\mathrm{NO}_{\mathrm{x}}$} & PT & 31 & 0.81 & 0.65 & 0.40 & 0.39 & 0.49 & 0.84 \\
\hline & & SP & 35 & 0.63 & 0.79 & 0.39 & 0.31 & 0.41 & 1.68 \\
\hline
\end{tabular}




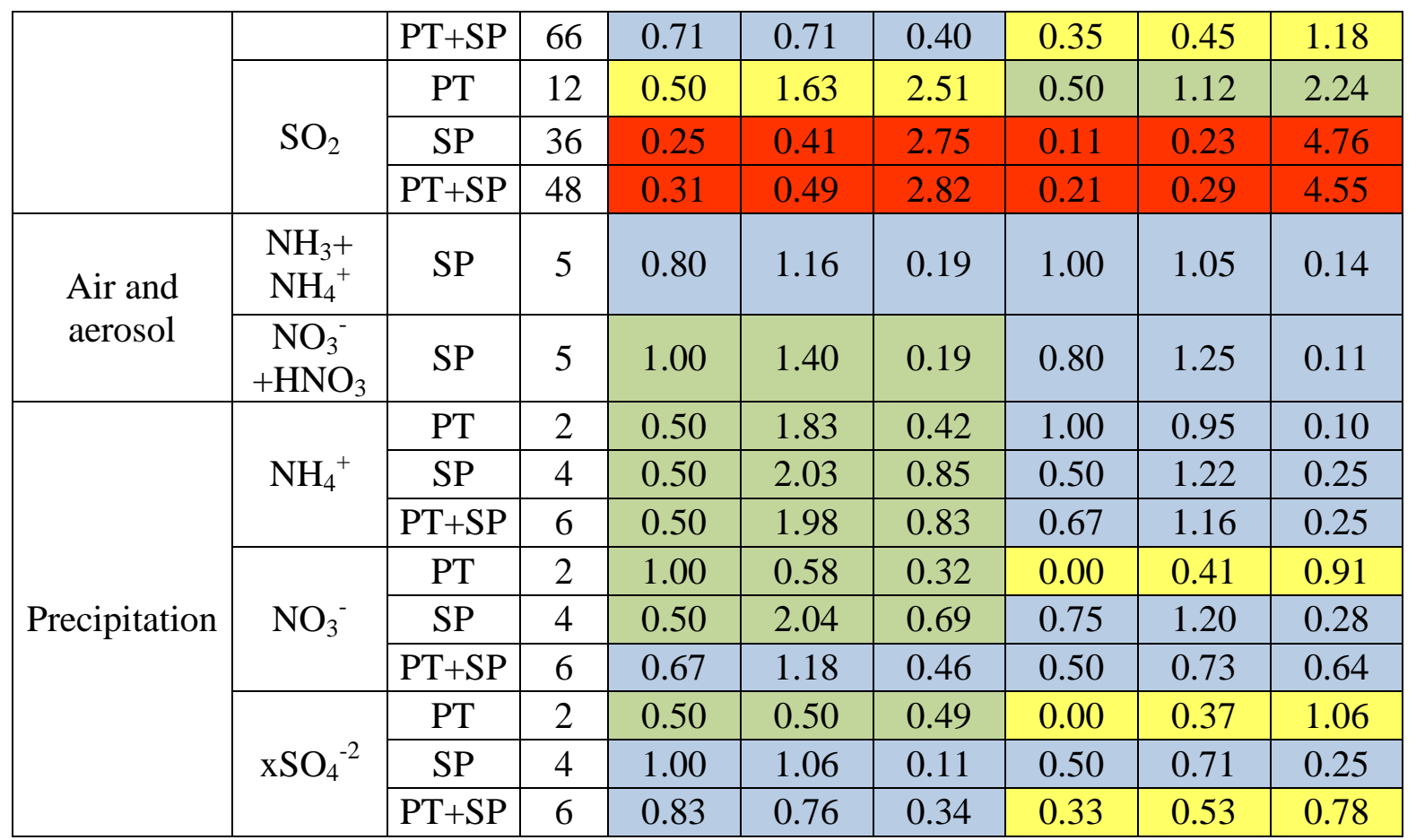

PT represents stations in Portugal, SP represents stations in Spain. The same information is provided for EMEP modelling results for comparison purposes. $* \mathrm{~N}$-number of observation points. Blue cells - fit for purpose; green cells - two out of three criteria were observed; yellow cells - one criterion was observed; red cells - no performance criteria were achieved

Across the whole domain, modelled $\mathrm{NO}_{\mathrm{x}}$ concentrations comply with the FAC2 criteria (71\%), the NMSE of 0.40 is below the recommended value of 1.5 , while the $\mathrm{FB}_{\mathrm{M} / \mathrm{O}}$ is 0.71 , representing a systematic underestimation of predicted values. This can be clearly seen for both Portuguese and Spanish datasets in Figure 4A. Modelled $\mathrm{SO}_{2}$ concentrations in the domain do not fulfil any of the criteria, showing an overestimation in Portugal $\left(\mathrm{FB}_{\mathrm{M} / \mathrm{O}}\right.$ of 1.63) resulting from weighting overestimation in some places and underestimation in others and a general underestimation in Spain (Figure 4B), which is reflected in $\mathrm{FB}_{\mathrm{M} / \mathrm{O}}$ of 0.49 within the domain.

$80 \%$ to $100 \%$ of modelled values of $\mathrm{NH}_{3}+\mathrm{NH}_{4}{ }^{+}$and of $\mathrm{NO}_{3}{ }^{-}+\mathrm{HNO}_{3}$ in the air and aerosols are within $\mathrm{FAC} 2$ of observations, while $\mathrm{FB}_{\mathrm{M} / \mathrm{O}}$ is under $30 \%$ and NMSE under 0.19 , indicating a good model fit for these species.

Regarding wet deposition, or concentration in the precipitation (Figure 5), the reduced nitrogen form $\left(\mathrm{NH}_{4}{ }^{+}\right)$fulfils two out of three performance criteria, with modelled values being overestimated, with a bias of 1.98. Model evaluation of concentration in the precipitation of the oxidized nitrogen form $\left(\mathrm{NO}_{3}{ }^{-}\right)$and reduced sulfur $\left(\mathrm{xSO}_{4}^{-2}\right)$ agrees with all performance criteria proposed by Chang \& Hanna $(2004,2005)$. Wet deposition of oxidized nitrogen is overestimated, with a bias of 1.18 , and wet deposition of oxidized sulfur in underestimated, with a bias of $0.76(24 \%)$.

Comparison between FRAME's and EMEP's results represented by performance criteria (Table II) show that, although EMEP performs better for some of the 
components, results using the FRAME model are fit for purpose for a higher number of components.

The spatial distribution of modelled concentrations of $\mathrm{NO}_{\mathrm{x}}, \mathrm{NH}_{3}$ and $\mathrm{SO}_{2}$ in the air, depicted in Figure 7, appear to follow the spatial pattern of emissions. These results show, together with scatter plots, contrasting concentrations of $\mathrm{NO}_{\mathrm{x}}, \mathrm{SO}_{2}$ and $\mathrm{NH}_{3}$ between Portugal and western Spain. Portugal shows higher concentrations of $\mathrm{NO}_{\mathrm{x}}$ and $\mathrm{SO}_{2}$, especially along the western coastline. Regarding $\mathrm{NH}_{3}$ concentrations, the opposite occurs: western Spain shows higher concentrations, and the abrupt change at the border between both countries reflect a similar contrast of $\mathrm{NH}_{3}$ emissions (Figure 2B).

Correspondingly, in activities related to livestock and agriculture, the Portuguese total of $\mathrm{NH}_{3}$ emissions within the domain is only $16 \%$ (Figure 2). Moreover, scattered grid cells containing higher $\mathrm{NH}_{3}$ concentrations correspond to $\mathrm{NH}_{3}$ LPS emission facilities, mostly comprising livestock sector activities (e.g. intensive rearing of poultry or pigs) (more information available in Figure S 2 of the supplementary materials).

\section{Figure 6: Spatial distribution of (A) $\mathrm{NO}_{x}$, (B) $\mathrm{NH}_{3}$ and (C) $\mathrm{SO}_{2}$ concentration in 2015 obtained using FRAME}

Wet and dry deposition maps for oxidized and reduced $\mathrm{N}$ and oxidized $\mathrm{S}$ are represented in Figure 7 (the same parameters from the EMEP model are presented in Figure S 14 of the supplementary materials). Wet deposition occurs in the northern part of the domain, in locations with higher precipitation, while dry deposition appears to follow the spatial pattern observed in emissions: oxidized $\mathrm{N}$ follows $\mathrm{NO}_{\mathrm{x}}$ emissions; reduced $\mathrm{N}$ shows a relationship with $\mathrm{NH}_{3}$ emissions; and $\mathrm{S}$ deposition follows $\mathrm{SO}_{\mathrm{x}}$ emissions, as expected.

Similarly to what was observed in the concentration maps, dry deposition shows a trend within the domain, with higher deposition of oxidized $\mathrm{N}$ and $\mathrm{S}$ along the coastline. Furthermore, reduced $\mathrm{N}$ deposition maps (wet and dry) (Figure 7B and E) also show higher background values in eastern parts of the domain.

Figure 7: Spatial distribution $N$ and $S$ deposition in 2015 obtained using FRAME. (A) wet deposition of oxidized $N$; (B) wet deposition of reduced $N$; (C) wet deposition of oxidized $S$; (D) dry deposition of oxidized $N$; (E) dry deposition of reduced $\mathrm{N}$; (D) dry deposition of oxidized $\mathrm{S}$

Total deposition values (wet and dry) of oxidized $\mathrm{N}$ and $\mathrm{S}$ and reduced $\mathrm{N}$, obtained with the FRAME and EMEP are presented in Table III (differentiated by landcover type in Table S V of the supplementary materials).

Table III: Total wet and dry deposited oxidized N, reduced N, and oxidized S contributions from Portugal and from the whole domain, obtained with FRAME and EMEP models 


\begin{tabular}{|c|c|c|c|c|c|c|c|c|c|}
\hline \multicolumn{2}{|c|}{ Components } & \multicolumn{2}{c|}{$\begin{array}{c}\text { Oxidized N } \\
(\text { Gg N) }\end{array}$} & \multicolumn{2}{c|}{$\begin{array}{c}\text { Reduced N } \\
(\text { Gg N })\end{array}$} & \multicolumn{2}{c|}{$\begin{array}{c}\text { Total N } \\
(\text { Gg N })\end{array}$} & \multicolumn{2}{c|}{$\begin{array}{c}\text { Sulfur } \\
(\text { Gg S })\end{array}$} \\
\hline \multirow{2}{*}{ Models } & $\begin{array}{c}\text { FRAM } \\
\text { E }\end{array}$ & $\begin{array}{c}\text { EME } \\
\text { P }\end{array}$ & $\begin{array}{c}\text { FRA } \\
\text { ME }\end{array}$ & $\begin{array}{c}\text { EME } \\
\text { P }\end{array}$ & $\begin{array}{c}\text { FRA } \\
\text { ME }\end{array}$ & $\begin{array}{c}\text { EME } \\
\text { P }\end{array}$ & $\begin{array}{c}\text { FRA } \\
\text { ME }\end{array}$ & $\begin{array}{c}\text { EME } \\
\text { P }\end{array}$ \\
\hline \multirow{2}{*}{ Portugal } & Wet dep. & 15 & 9 & 18 & 11 & 33 & 20 & 11 & 7 \\
\cline { 2 - 11 } & Dry dep. & 13 & 12 & 18 & 12 & 31 & 25 & 8 & 6 \\
\hline \multirow{3}{*}{ Spain } & Wet dep. & 41 & 22 & 63 & 39 & 104 & 60 & 29 & 19 \\
\cline { 2 - 11 } & Dry dep. & 27 & 23 & 55 & 36 & 82 & 58 & 14 & 9 \\
\hline \multirow{3}{*}{ Domain } & Wet dep. & 56 & 31 & 81 & 50 & 137 & 80 & 40 & 26 \\
\cline { 2 - 10 } & Dry dep. & 40 & 35 & 73 & 48 & 113 & 83 & 22 & 15 \\
\cline { 2 - 10 } & Total dep. & 96 & 65 & 155 & 98 & 250 & 163 & 62 & 41 \\
\hline
\end{tabular}

$490 \mathrm{~N}$ and $\mathrm{S}$ deposition rates are similar between landcover types, being slightly higher for forests and urban areas, respectively. For all land cover types, reduced $\mathrm{N}$ deposition is higher than oxidized $\mathrm{N}$ deposition (averaging 61\% against 39\%). There is more wet deposition than dry deposition across all landcover types (averaging $56 \%$ for $\mathrm{N}$ and $66 \%$ for S, respectively), except for urban areas (48\% for $\mathrm{N}$ and $47 \%$ for $\mathrm{S}$, respectively).

Total deposition values of $\mathrm{N}$ and $\mathrm{S}$ throughout the domain obtained with the FRAME model are higher than the values obtained with the EMEP model. Contrasts between models are higher for wet deposition and for N, showing a consistent ratio of $\sim 1.7$ within the domain. Dry deposition obtained with FRAME is also higher, by a ratio of $\sim$ 1.3. For S, differences are also higher for wet deposition (increase in a factor of 1.5) than for dry deposition (decrease in a factor of 1.4).

Differences between models have significant implications in both $\mathrm{N}$ and $\mathrm{S}$ deposition within the domain. $\mathrm{N}$ and $\mathrm{S}$ deposition determined by FRAME is significantly higher, which can be observed in both the spatial distribution (see Figure 7 and Figure 8 for deposition obtained with FRAME and Figure S 14 and S 15 in the supplementary materials for deposition obtained with EMEP) and in national totals (Table III). In general, regions with higher $\mathrm{N}$ and $\mathrm{S}$ deposition are the same, however the magnitude of deposition is different. For example, results obtained with FRAME estimate $\mathrm{N}$ deposition below $5 \mathrm{~kg} \mathrm{~N} \cdot \mathrm{ha}^{-1} \cdot$ year $^{-1}$ in only $5 \%$ of the territory (against $53 \%$ obtained with EMEP), between $5-10 \mathrm{~kg} \mathrm{~N} \cdot \mathrm{ha}^{-1} \cdot \mathrm{year}^{-1}$ in $78 \%$ (against $44 \%$ with EMEP) and between $10-20 \mathrm{~kg} \mathrm{~N} \cdot \mathrm{ha}^{-1} \cdot$ year $^{-1}$ in $17 \%$ (against $1.7 \%$ with EMEP). Moreover, FRAME dry deposition maps allow to identify a larger number of deposition hotspots, which are diluted in the EMEP maps due to the averaging over larger areas

Spatial patterns in total deposition (Figure 8) show higher $\mathrm{N}$ deposition in the northern and eastern part of the domain, reflecting a larger contribution from reduced $\mathrm{N}$.

Accordingly, and similarly to $\mathrm{NH}_{3}$ concentration maps, scattered grid cells containing higher $\mathrm{N}$ deposition are related to $\mathrm{NH}_{3}$ LPS livestock husbandry facilities. $\mathrm{N}$ deposition throughout the domain ranges from 3 to $38.6 \mathrm{~kg} \mathrm{~N} \cdot \mathrm{ha}^{-1} \cdot$ year $^{-1}$, averaging $\sim 8 \mathrm{~kg} \mathrm{~N} \cdot \mathrm{ha}^{-}$ ${ }^{1}$. year $^{-1}$ across the domain and $\sim 7 \mathrm{~kg} \mathrm{~N} \cdot \mathrm{ha}^{-1} \cdot$ year $^{-1}$ in mainland Portugal.

$\mathrm{S}$ deposition is higher along the coastline (Figure $8 \mathrm{~B}$ ). Maximum values occur around LPS of $\mathrm{SO}_{\mathrm{x}}$ emissions, related to the production of energy and industrial activities (for more information consult the supplementary materials, Figure S $3 \mathrm{~A}$ and B), while background values follow the spatial pattern of precipitation and of $\mathrm{SO}_{\mathrm{x}}$ emissions 
related with shipping, represented by higher deposition (more information available in Figure $\mathrm{S} 3$ of the supplementary materials). S deposition throughout the domain ranges from 0.9 to $60 \mathrm{~kg} \mathrm{~S} \cdot \mathrm{ha}^{-1} \cdot$ year $^{-1}$, averaging $\sim 2 \mathrm{~kg} \mathrm{~S} \cdot \mathrm{ha}^{-1} \cdot$ year $^{-1}$ in both the domain and in mainland Portugal.

Figure 8: (A) Total N deposition and (B) total S deposition in 2015 within the SW Europe domain (Western Iberia: Portugal and W Spain) obtained using FRAME; (C) Delimitation of functional urban areas (OECD, 2016; 2019) and location of LPS related with industries and respective $\mathrm{NO}_{\mathrm{x}}, \mathrm{NH}_{3}$ and $\mathrm{SO}_{\mathrm{x}}$ emissions (The European Pollutant Release and Transfer Register, 2018)

\section{Discussion}

Model results for western Iberia were evaluated using independent measurement data from air quality monitoring stations in mainland Portugal and western Spain. This evaluation revealed that all maps for $\mathrm{N}$ pollutants were fit for purpose (following the criteria set by Hanna \& Chang, 2010). Therefore, this work represents a significant improvement over existing maps (such as the EMEP model), both in terms of spatial resolution and evaluation results. The FRAME model performs better than the EMEP model within the domain as follows: (1) The EMEP model uses a lower vertical (20 layers instead of 33) and horizontal resolution ( $10 \mathrm{~km} \times 10 \mathrm{~km}$ instead of $5 \mathrm{~km} \times 5 \mathrm{~km})$; (2) EMEP is intended to evaluate pollution concentration and deposition at the European scale and is more focused on detecting the amount of transboundary pollutants rather than identifying local hotspots within countries.

Similar differences in reduced $\mathrm{N}$ concentrations and deposition obtained with both models have been attributed to the both the low resolution of EMEP and the large height of the lowest layer $(90 \mathrm{~m})$, which makes it difficult to simulate the large vertical gradient of ammonia above sources (van Pul et al., 2009b; Kryza et al., 2010). Differences in deposition have significant implications on the identification and magnitude of deposition hotspots, which are diluted in the EMEP maps due to averaging over larger areas. This is particularly relevant for the determination of critical loads exceedances and for the protection of ecosystems. In Europe, the protection of ecosystems focuses foremost on the Natura 2000 network, which includes regions of core breeding and resting sites for rare and threatened species. Empirical $\mathrm{N}$ critical loads (CLs) summarized in Bobbink and Hettelingh (2011) are available for only $36 \%$ of the region contained within the Iberian Peninsula's Natura 2000 reserves. Regardless, and for the ecosystems with available CLs, the comparison of $\mathrm{N}$ deposition obtained with FRAME with minimum CLs indicates that $38 \%$ Natura 2000 sites are at risk of eutrophication (Figure S 16A and Table S VII in the supplementary materials). This value more than triples the $12 \%$ obtained with $\mathrm{N}$ deposition maps from EMEP (Figure $\mathrm{S}$ $16 \mathrm{~B}$ and Table S VII in the supplementary materials). Considering that there is still no information regarding ecosystem specific CLs for $64 \%$ of the territory within the reserves, the areas with ecosystems at risk of eutrophication are likely to be much larger than reported. 
Model results presented here meet all performance criteria suggested by Chang \& Hanna $\left(2004\right.$, 2005) for air concentration of $\mathrm{NO}_{\mathrm{x}}$, air and aerosol concentration of $\mathrm{NH}_{3}+\mathrm{NH}_{4}{ }^{+}$and for wet deposition of $\mathrm{S}$ and oxidized $\mathrm{N}$. For air and aerosol concentration of $\mathrm{NO}_{3}{ }^{-}+\mathrm{HNO}_{3}$ and for wet deposition of reduced nitrogen (concentration of $\mathrm{NH}_{4}{ }^{+}$in the precipitation), two out of three performance criteria (FAC2 $\geq 50 \%$ and NMSE $\leq 1.5$ ) were met. Finally, and only for air concentration of $\mathrm{SO}_{2}$, no performance criteria were met. Under and over-predictions obtained by FRAME in different components shows an overall similar trend to EMEP modelling bias within the domain. In particular, the overestimation of $\mathrm{N}$ wet deposition may be partially attributed to an overestimation of higher precipitation values, which has been detected as a frequent source of uncertainty in air pollution modelling (cf. Im et al., 2013, Dore et al., 2015). Furthermore, it could also be a result of an overestimation of $\mathrm{N}$ concentration in the air, deriving from the reduced form, ammonia, given that FRAME underestimated $\mathrm{NO}_{\mathrm{x}}$. Unfortunately, there are no observations of atmospheric $\mathrm{NH}_{3}$ concentrations available within the domain to either support or contradict this possibility.

There are large contrasts of oxidized $\mathrm{N}$ and $\mathrm{S}$ concentrations and deposition between the Portuguese and Spanish regions of the domain. This is particularly evident along the coast, downwind of the international shipping routes, and can be attributed to shipping emissions reaching the coastal grid cells. The large influence of international shipping emissions on the deposition in coastal regions has been addressed by Dore et al. (2007). This interpretation is also supported by the work of Gauss et al. (2016a, b), which indicated that the contribution to $\mathrm{S}$ and oxidized $\mathrm{N}$ deposition in Portugal and Spain due to international shipping in 2014 reached $25 \%$ and $19 \%$, respectively, and that $\mathrm{N}$ and $\mathrm{S}$ deposition due to transboundary air pollution in coastal grid cells represents, in general, over $60 \%$, reaching $100 \%$ in some locations.

However, emissions from international shipping are not the only reason for the existing contrast between the two countries. Performance criteria for modelling results revealed a different spatial pattern in the Portuguese and Spanish regions of the domain for $\mathrm{SO}_{2}$ concentrations in the air: Portuguese predictions are generally overestimated, showing both high magnitude under and over predictions (reaching 3-4 $\mu \mathrm{g} \cdot \mathrm{m}^{-3}$ ), while Spanish predictions are mostly highly underestimated. This is also visible in the EMEP modelling results. The presence of both over and under predictions has been described by other authors (cf. Fournier et al., 2004) and attributed to the aggregated character of the LPS information available. A better LPS emission inventory, separating contributions from low-level sources (below $\sim 10 \mathrm{~m}$ ) from higher emissions related to combustion products from the smokestacks (above $\sim 30 \mathrm{~m}$ ), could allow better vertical discrimination of emissions being fed into the model. Instead, emissions from these LPS are exclusively allocated to smoke-stack elevations, which generates lower $\mathrm{SO}_{2}$ near the emission sources and higher concentrations further away. For the Spanish region of the domain the situation is different as large under-estimations frequently occur (results in this paper and in Gauss et al., 2017). This could be related to one or a combination of several possibilities: (1) under-estimation of $\mathrm{SO}_{\mathrm{x}}$ emissions; (2) exclusion of relevant wind components carrying pollutants from regions located in the eastern of the domain; (3) overestimated $\mathrm{NH}_{3}$ emissions which interact with $\mathrm{SO}_{2}$ forming sulphate aerosol; (4) or another systematic bias as yet unknown. 
612 The influence of site-specific wind regimes in the Mediterranean has been identified by 613 other authors as the main reason for poor model performance. Fagerli et al. (2017)

614 attributed lower modelled aerosols at high temporal resolution observed in Spain to 615 west-directed wind components originated in the Mediterranean during the summer. In 616 fact, Spain is characterized by regions with strong seasonal variations in the main wind 617 direction, which contrast with a generalized west-ward tendency observed in Portugal 618 (cf. Lorente-Plazas et al., 2015). If this were the case, one would expect that $\mathrm{N}$ 619 concentration would show the same pattern. However, there is no under-estimation of $\mathrm{N}$ 620 concentration in the air in the Spanish part of the domain and there is even a slight 621 overestimation in aerosols. Given this scenario, it is highly unlikely that winds crossing 622 regions such as Madrid and the south-facing Spanish Mediterranean coastline, which 623 are relevant sources of $\mathrm{SO}_{2}$ and $\mathrm{NO}_{\mathrm{x}}$ emissions (from industry/domestic fuel 624 combustion and international shipping, respectively), exclusively contribute with a 625 significant amount of $\mathrm{SO}_{2}$ that is then transported within our domain.

626 Furthermore, the presence of high $\mathrm{NH}_{3}$ concentrations contributes to the formation of 627 sulphate aerosol, by reaction with $\mathrm{SO}_{2}$ (Fournier et al., 2004; Vieno et al., 2010). In fact, $628 \mathrm{NH}_{3}$ emissions derived from the Spanish region of the domain are much higher than 629 those derived from Portugal, mostly related to livestock production and agricultural 630 activities, which can be seen by comparing both sides of the border (more information 631 available in Figure $\mathrm{S} 2$ of the supplementary materials). An overestimation of $\mathrm{NH}_{3}$ 632 emissions in the Spanish region of the domain could be responsible for the removal of a 633 higher proportion of the $\mathrm{SO}_{2}$ and cause its under-estimation. Unfortunately, $\mathrm{NH}_{3}$ 634 observations are too few and far between, and can only give us a general idea of model 635 performance and there are no observations of sulphate aerosol within the domain to 636 cross-check with modelling results. However, there is no clear indication of 637 overestimation in the air and aerosol concentration of $\mathrm{NH}_{3}+\mathrm{NH}_{4}{ }^{+}$nor of $\mathrm{xSO}_{4}{ }^{-2}$ in 638 precipitation. Although there is a significant over-estimation of wet deposition of 639 reduced $\mathrm{N}(\sim 98 \%)$, the spatial distribution of this component reflects the precipitation, 640 most likely representing an overestimation in precipitation, rather than of $\mathrm{NH}_{3}$ 641 emissions. Furthermore, the large contrast between Portuguese and Spanish $\mathrm{NH}_{3}$ 642 emissions also appears in independent $\mathrm{NH}_{3}$ emission inventories based on mixed 643 bottom-up and top-down methodologies for livestock and agriculture activities, 644 respectively (cf. Moran et al., 2016). This further weakens the hypothesis of the 645 overestimation of $\mathrm{NH}_{3}$ emissions as the reason for low $\mathrm{SO}_{2}$ concentrations in Spain. To 646 further test this hypothesis, we ran an additional simulation with the FRAME model, 647 and reduced the $\mathrm{NH}_{3}$ emissions by $50 \%$ within the domain. Results show that, in this 648 new scenario, performance criteria for $\mathrm{SO}_{2}$ concentrations within the domain are even 649 worse than before and continue to show an underestimation of this pollutant in Spain 650 (more information available in Table S VIII of the supplementary materials). All this 651 information combined indicates that the underprediction of $\mathrm{SO}_{2}$ is not the result of 652 excess $\mathrm{NH}_{3}$.

653 Summarizing, the most logical conclusion is that the source of low modelled $\mathrm{SO}_{2}$ 654 concentration in the Spanish region of the domain is related to an under-estimation of $655 \mathrm{SO}_{\mathrm{x}}$ emissions. Taking this into consideration, and assuming that the spatial pattern in $\mathrm{S}$ 656 deposition in Portugal is close to reality, the use of the resulting $\mathrm{S}$ deposition map as an 657 absolute tool is, at this time, premature. Regarding N concentration and deposition, 
model results are fit for purpose and the maps presented in this work correspond to the best available knowledge for Portugal. Moreover, differences between nitrogen deposition in Portugal and in the Spanish region of the domain are most probably real and represent differences in production volumes associated with livestock and agriculture (Henrard \& Forti, 2016).

Within the domain, $\mathrm{N}$ deposition is mostly dominated by reduced $\mathrm{N}(62 \%)$, with the oxidized form prevailing in urban and industrial areas and in coastal locations. This trend is commonly observed across central-western Europe, where oxidized $\mathrm{N}$ deposition has been shown to be more prevalent in urban and industrial areas (Hertel et al., 2011). Estimated and measured $\mathrm{N}$ deposition at 4 measurement stations in Mediterranean forests in Spain showed a dominance of oxidized forms ( 69\%) over reduced forms of N (cf. García-Gómez, et al., 2018). These values contrast with lower contributions of oxidized forms obtained using FRAME (minimum of 38\% across arable, grass and forests and maximum of $41 \%$ across urban areas) and differences could be related to a proximity between $\mathrm{NO}_{\mathrm{x}}$ emissions and the measurement stations used in the Spanish study, which are mostly peri-urban. Taking this into consideration, and given the similar pattern of emissions and deposition, actions to reduce total nitrogen deposition should focus on target areas, e.g. in urban areas on reducing $\mathrm{NO}_{\mathrm{x}}$ emissions from transport and from industrial activities. This will have the added benefit of reducing pollution affecting human health (Sustainable Development Goal 3.9 in United Nations, 2015). In rural areas, the focus should be on reducing $\mathrm{NH}_{3}$ emissions, which are mostly related to agriculture/livestock activities. This is critical for protecting biodiversity because, as in many Mediterranean countries, biodiversity-rich areas occur close to or even dependent on some agricultural activity (cf. Pinho et al., 2018).

The relative contributions of dry and wet $\mathrm{N}$ deposition seem balanced across the domain (55\% wet deposition, $53 \%$ over forests), contrasting with $\sim 77 \%$ contribution of dry deposition measured in Spanish forests (García-Gómez, et al., 2018). This suggests that dry deposition could be underestimated by FRAME when applied to Mediterranean countries, possibly due to model parameterizations being focused on UK conditions (Smith et al., 2000). Model results suggest that, in general, dry deposition occurs mainly in coastal areas, which comprise higher urban density and consequently, higher emissions. Taking into consideration climate change scenarios which suggest a generalized increase of aridity (due to increased evapotranspiration) and agricultural intensification (Lickley \& Solomon, 2018), an increase of dry deposition is to be expected. Nitrogen dry deposition creates higher concentrations at the vegetation surface, when compared to wet deposition (Levy et al., 2018), implying that the impact of nitrogen on biodiversity may increase in the future, due to an expected increase in dry deposition under climate change.

696 The average contribution to $\mathrm{S}$ deposition across western Iberia, of $\sim 2 \mathrm{~kg} \mathrm{~S} \cdot \mathrm{ha}^{-1} \cdot \mathrm{year}^{-1}$, is 697 lower than the 2015 European average of $5.8 \mathrm{~kg} \mathrm{~S} \cdot \mathrm{ha}^{-1} \cdot$ year $^{-1}$ (Engart et al., 2017) and 698 significantly lower than average measurements made in Northern China up to 2010, of $69964.8 \mathrm{~kg} \mathrm{~S} \cdot \mathrm{ha}^{-1} \cdot \mathrm{yr}^{-1}$ (Pan et al., 2013). In what concerns average $\mathrm{N}$ deposition around 7002015 , the value obtained for the domain, of of $8.2 \mathrm{~kg} \mathrm{~N} \cdot \mathrm{ha}^{-1} \cdot \mathrm{yr}^{-1}$, is higher than global 701 averages $\left(<2 \mathrm{~kg} \mathrm{~N} \cdot \mathrm{ha}^{-1} \cdot \mathrm{yr}^{-1}\right)$, but similar to European averages of $7-8 \mathrm{~kg} \mathrm{~N} \cdot \mathrm{ha}^{-1} \cdot \mathrm{yr}^{-1}$ 702 (Engart et al., 2017; Ackerman et al., 2019). However, it is substantially lower than the 703 largest worldwide deposition rate above $50 \mathrm{~kg} \mathrm{~N} \cdot \mathrm{ha}^{-1} \cdot \mathrm{yr}^{-1}$ estimated for Central China (Jia et al., 2016; Engart et al., 2017; Ackerman et al., 2019). 
One major difficulty associated with air pollution modelling for the study area is the

706 lack of observations to evaluate model performance. This is especially true for

707 systematic $\mathrm{NH}_{3}$ concentration monitoring, which is absent throughout the entire

708 domain. The available measurements correspond to a small number of stations, all

709 located in Spain, measuring combined gaseous and particle phases. The same situation

710 occurs with stations measuring wet deposition, for which there are only 6 stations

711 available throughout the domain (2 in Portugal and 4 in Spain). Ultimately, the higher

712 the number and denser the spatial coverage of observations used in model evaluation,

713 the higher the confidence in modelling results. The lack of spatial coverage of

714 measurement stations, especially for ammonia, has been identified has a limiting factor

715 in model evaluation (Benedictow et al., 2010; Gauss et al., 2017). To improve

716 concentration/deposition modelling, and no matter how accurate the input data are, an

717 adequate number of spatially dispersed and regionally representative observations are

718 required. This greatly reinforces the need to establish a systematic monitoring network

719 measuring atmospheric ammonia concentrations in Portugal and also the need to add

720 more measurements of wet deposition.

\section{5. Conclusions}

722 Here we provide $5 \mathrm{~km} \times 5 \mathrm{~km}$ resolution maps for atmospheric $\mathrm{N}$ and $\mathrm{S}$ pollution in the

723 western Iberian Peninsula, using the FRAME model. These maps represent a significant improvement from the existing available information from the EMEP model with a $\sim 10 \mathrm{~km} \times 10 \mathrm{~km}$ resolution. The FRAME model proved fit for purpose for $\mathrm{N}$ and these results comprise a stepping stone for future refinement of horizontal model resolution.

$\mathrm{N}$ deposition presents a larger contribution from reduced $\mathrm{N}$, reflecting $\mathrm{NH}_{3}$ emissions which are mostly associated with livestock farming and other agricultural activities. Tackling farming emissions in addition to combustion sources is essential when applying abatement strategies to meet the NEC Directive, for meeting national targets. Results also show that efforts to reduce $\mathrm{N}$ pollution in western Iberia should be mostly focused on reducing $\mathrm{NH}_{3}$ emissions in rural areas and, to a lesser extent, $\mathrm{NO}_{\mathrm{x}}$ emission in urban and industrial areas.

734 Climate change may contribute to an increased importance of dry deposition of $\mathrm{N}$ and increase the negative impacts of excess atmospheric $\mathrm{N}$ on biodiversity. We also identify that key improvements for the existing Portuguese air quality monitoring network should focus on establishing a national network for measuring concentrations of reduced nitrogen $\left(\mathrm{NH}_{3}, \mathrm{NH}_{4}^{+}\right)$and on improving the density of stations measuring wet $\mathrm{N}$ deposition.

\section{Acknowledgements}

741 Article preparation was supported by project NitroPortugal (European Union's Horizon 7422020 research and innovation programme under grant agreement No 692331). Pedro 743 Pinho acknowledges EC (H2020 BiodivERsA32015104 "BioVeins") for funding.

744 This work was partly supported by the Natural Environment Research Council award

745 number NE/R016429/1 as part of the UK-SCAPE programme delivering National 746 Capability. 
We acknowledge João Matos, Dília Jardim (Agência Portuguesa do Ambiente),

748 Diamantino Henriques (Instituto Português do Mar e da Atmosfera), Paulo Beliche

749 (Comissão de Coordenação e Desenvolvimento Regional do Alentejo) and Teresa Costa

750 Pereira (Agência Portuguesa do Ambiente) for on-occasion inputs, crucial in the

751 resolution of specific questions that aided the development of this work.

\section{Data Availability}

753 Datasets related to this article can be found at http://dx.doi.org/10.17632/9482zcmdfb.1, hosted at Mendeley Data (Oliveira et al., 2019). EMEP model results were downloaded from the EMEP webpage, at https://www.emep.int $/ \mathrm{mscw} / \mathrm{mscw}$ moddata.html (The Norwegian Meteorological Institute, 2018). Gridded emissions used in the modelling were downloaded from the EMEP webpage, at http://www.ceip.at/ms/ceip_home1/ceip_home/new_emep-grid/01_grid_data/ (EMEP/CEIP, 2018). Large point source emissions used in the FRAME run were downloaded from the E-PRTR webpage, at https://www.eea.europa.eu/ds_resolveuid/d713ba1cc9374b9a95eea07531f62e6c (The European Pollutant Release and Transfer Register, 2018). Measurements used in model evaluation were downloaded from the European Environment Agency website, at https://www.eea.europa.eu/ds_resolveuid/b21a537e763e4ad9ac8ccffe987d6f77 (European Environment Agency, 2018); from the Norwegian Institute for Air Research website, at http://ebas.nilu.no/ (Norwegian Institute for Air Research, 2017); and from the Agência Portuguesa do Ambiente website, at https://qualar1.apambiente.pt/qualar/index.php?page=6 (Agência Portuguesa do Ambiente, 2017). Landcover data was downloaded from the European Union webpage, at https://www.eea.europa.eu/data-and-maps/data/external/corine-land-cover-2012 (European Union, 2017).

\section{References}

Ackerman, D., Millet, D. B., \& Chen, X. (2019). Global estimates of inorganic nitrogen https://doi.org/10.1029/2018GB005990

[dataset] Agência Portuguesa do Ambiente, Air quality monitoring data in Portugal, Available at https://qualar1.apambiente.pt/qualar/index.php?page=6, Accessed 27-102017

Andrade, C. \& Corte-Real, J. A. (2015). Spatial distribution of climate indices in the Iberian Peninsula. In Proceedings of the International Conference on Numerical Analysis and Applied Mathematics 2014 (ICNAAM-2014). AIP Publishing. https://doi.org/10.1063/1.4912413

ApSimon, H. M., Barker, B. M., \& Kayin, S. (1994). Modelling studies of the atmospheric release and transport of ammonia in anticyclonic episodes. Atmospheric Environment 28(4), 665-678. https://doi.org/10.1016/1352-2310(94)90043-4

Barros, C., Pinho, P., Durão, R., Augusto, S., Máguas, C., Pereira, M. J. \& Branquinho, C. (2015). Disentangling natural and anthropogenic sources of atmospheric sulfur in an industrial region using biomonitors. Environmental Science \& Technology 49, 22222229. https://doi.org/10.1021/es505292t 
[dataset] Bealey, W. J. \& Dore, A. J. (2017). Source Attribution - deposition of nitrogen and sulphur to UK. NERC Environmental Information Data Centre. https://doi.org/10.5285/e5bfac9b-0642-4b5b-a780-e5801b2dab8b

Benedictow, A., Berge, H., Fagerli, H., Gauss, M., Jonson, J. E., Nyíri, A., Simpson, D., Tsyro, S., Valdebenito, A., Shamsudheen, S. V., Wind,P., Aas, W., Hjellbrekke, A.-G., Mareckova, K., Wankmüuller, R., Iversen, T., Kirkevåg, A., Seland, O., Haugen, E. \& Mills, G. (2010). Transboundary Acidification, Eutrophication and Ground Level Ozone in Europe in 2008 - EMEP Status Report 2010. Norwegian Meteorological Institute.

Benito- Calvo, A., Pérez- González, A., Magri, O., \& Meza, P. (2009). Assessing regional geodiversity: the Iberian Peninsula. Earth Surface Processes and Landforms 34(10), 1433-1445. https://doi.org/10.1002/esp.1840

Bivand, R., Keitt, T. \& Rowlingson, B. (2018). rgdal: Bindings for the 'Geospatial' Data Abstraction Library. R package version 1.2-18. https://CRAN.Rproject.org/package $=$ rgdal

Bobbink, R. \& Hettelingh, J. P. (2011). Review and revision of empirical critical loads and dose-response relationships: Proceedings of an expert workshop, Noordwijkerhout, 23-25 June 2010. Rijksinstituut voor Volksgezondheid en Milieu RIVM.

Bytnerowicz, A. \& Fenn, M. E. (1996). Nitrogen deposition in California forests: A review. Environmental Pollution 92(2), 127-146. https://doi.org/10.1016/02697491(95)00106-9

Cape, J. N., Tang, Y. S., can Dijk, N., Love, L., Sutton, M. A. \& Palmer, S. C. F. (2004). Concentrations of ammonia and nitrogen dioxide at roadside verges, and their contribution to nitrogen deposition. Environmental Pollution 132, 469-478. https://doi.org/10.1016/j.envpol.2004.05.009

Chang, J. C. \& Hanna, S. R. (2004). Air quality model performance evaluation. Meteorology and Atmospheric Physics 87, 167-196. https://doi.org/10.1007/s00703003-0070-7

Chang, J. C. \& Hanna, S. R. (2005). Technical descriptions and user's guide for the BOOT statistical model evaluation software package, version 2.0. George Mason University, 4400, 22030-4444.

Chen, T.-M., Gokhale, J., Shofer, S. \& Kuschner, W. G. (2007). Outdoor Air Pollution: Nitrogen Dioxide, Sulfur Dioxide, and Carbon Monoxide Health Effects. The American Journal of the Medical Sciences 333(4), 249-256. https://doi.org/10.1097/MAJ.0b013e31803b900f

Council Directive 92/43/EEC of 21 May 1992 on the conservation of natural habitats and of wild fauna and flora OJ L 206, 22.7.1992, p.7-50.

Directive (EU) 2016/2284 of the European Parliament and of the Council of 14 December 2016 on the reduction of national emissions of certain atmospheric pollutants, amending Directive 2003/35/EC and repealing Directive 2001/81/EC.

Dore, A. J., Vieno, M., Tang, Y. S., Dragosits, U., Dosio, A., Weston, K. J., \& Sutton, M. A. (2007). Modelling the atmospheric transport and deposition of sulphur and nitrogen over the United Kingdom and assessment of the influence of $\mathrm{SO}_{2}$ emissions 
832 from international shipping. Atmospheric Environment 41(11), 2355-2367.

833 https://doi.org/10.1016/j.atmosenv.2006.11.013

834 Dore, A., Kryza, M., Hallsworth, S., Matejko, M., Hall, J., van Oijen, M., Zhang, Y.,

835 Bealey, B., Vieno, M. Tang, S., Smith, R., Dragosits, U. \& Sutton, M. (2009).

836 Modelling the Deposition and Concentration of Long Range Air Pollutants: Final

837 Report. NERC/Centre for Ecology \& Hydrology.

838 Dore, A. J., Kryza, M., Hall, J. R., Hallsworth, S., Keller, V. J. D., Vieno, M., \& Sutton,

839 M. A. (2012). The influence of model grid resolution on estimation of national scale

840 nitrogen deposition and exceedance of critical loads. Biogeosciences 9(5), 1597-1609.

841 https://doi.org/10.5194/bg-9-1597-2012

842 Dore, A. J., Carslaw, D. C., Braban, C., Cain, M., Chemel, C., Conolly, C., Derwent, R.

843 G., Griffiths, S. J., Hall, J., Hayman, G., Lawrence, S., Metcalfe, S. E., Redington, A.

844 Simpson, D., Sutton, M. A., Sutton, P., Tang, Y.S., Vieno, M., Werner, M. \& Whyatt, J.

845 D. (2015). Evaluation of the performance of different atmospheric chemical transport

846 models and inter-comparison of nitrogen and sulphur deposition estimates for the UK.

847 Atmospheric Environment 119, 131-143.

848 https://doi.org/10.1016/j.atmosenv.2015.08.008

849 Dragosits, U., Theobald, M. R., Place, C. J., Lord, E., Webb, J., Hill, J., ApSimon, H.

850 M. \& Sutton, M. A. (2002). Ammonia emission, deposition and impact assessment at

851 the field scale: a case study of sub-grid spatial variability. Environmental Pollution 117,

852 147-158. https://doi.org/10.1016/S0269-7491(01)00147-6

853 Dragosits, U., Theobald, M. R., Place, C. J., ApSimon, H. M. \& Sutton, M. A. (2006).

854 The potential for spatial planning at the landscape level to mitigate the effects of

855 atmospheric ammonia deposition. Environmental Science and Policy 9, 626-638.

856 https://doi.org/10.1016/j.envsci.2006.07.002

857 Ellermann, T., Nygaard, J., Christensen, J. H., Løfstrøm, P., Geels, C., Nielsen, I. E.

858 Poulsen, M. B., Monies, C., Gyldenkærne, S., Brandt, J. \& Hertel, O. (2018). Nitrogen

859 Deposition on Danish Nature. Atmosphere 9, 447.

860 https://doi.org/10.3390/atmos9110447

861 [dataset] EMEP/CEIP, Spatially distributed emission data as used in EMEP models.

862 Available at http://www.ceip.at/ms/ceip_home1/ceip_home/new_emep-

863 grid/01_grid_data/, Accessed 12-04-2018.

864 Engardt, M., Simpson, D., Schwikowski, M. \& Granat, L. (2017). Deposition of sulphur 865 and nitrogen in Europe 1900-2050. Model calculations and comparison to historical

866 observations. Tellus B: Chemical and Physical Meteorology 69(1), 1328945,

867 https://doi.org/10.1080/16000889.2017.1328945

868 Erisman, J. W., van Grinsven, H., Grizzetti, B., Bouraoui, F., Powlson, D., Sutton, M.

869 A., Bleeker, A. \& Reis, S. (2011). The European nitrogen problem in a global

870 perspective. In Mark A. Sutton, Clare M. Howard, Jan Willem Erisman, Gilles Billen,

871 Albert Bleeker, Peringe Grennfelt, Hans van Grinsven and Bruna Grizzetti (Eds): The

872 European Nitrogen Assessment. Cambridge University Press. 
[dataset] European Environment Agency, Air Quality e-Reporting, Available at https://www.eea.europa.eu/ds_resolveuid/b21a537e763e4ad9ac8ccffe987d6f77, Accessed 13-09-2018

[dataset] European Union, Copernicus Land Monitoring Service, Corine Land Cover 2012, European Environment Agency (EEA)". Available at https://www.eea.europa.eu/data-and-maps/data/external/corine-land-cover-2012, Accessed 23-11-2017

Fagerli, H., Tsyro, S., Denby, B.R., Nyíri, A., Gauss, M., Simpson, D., Wind, P., Benedictow, A., Jonson, J. E., Klein, H., Schulz, M., Griesfeller, J., Aas, W., Hjellbrekke, A.-G., Solberg, S., Platt, S. M., Fiebig, M., Yttri, K.E., Rud, R. O., Tørseth, K., Mareckova, K., Pinterits, M., Tista, M., Ullrich, B., Wankmüller, R., Posch, M., Bergström, R., Imhof, H., Minguillón, M. C., Putaud, J.-P., Cavalli, F., Poulin, L., Schlag, P., Heikkinen, L. M., Swietlicki, E., Martinsson, J., Vana, M., Smejkalova, A. H., Kouvarakis, G. \& Mihalopoulos, N. (2017). Transboundary particulate matter, photo-oxidants, acidifying and eutrophying components. EMEP Report 1/2017. Norwegian Meteorological Institute.

Fournier, N. (2002). Development of an Atmospheric Transport Model Simulating Concentration and Deposition of Reduced Nitrogen over the British Isles. PhD thesis. University of Edinburgh.

Fournier, N., Dore, A. J., Vieno, M., Weston, K. J., Dragosits, U., \& Sutton, M. A. (2004). Modelling the deposition of atmospheric oxidised nitrogen and sulphur to the United Kingdom using a multi-layer long-range transport model. Atmospheric Environment 38(5), 683-694. https://doi.org/10.1016/j.atmosenv.2003.10.028

Frick, G. M. \& Hoppel, W. A. (2000). Airship measurements of ship's exhaust plumes and their effect on marine boundary layer clouds. Journal of the Atmospheric Sciences 57(16), 2625-2648. https://doi.org/10.1175/15200469(2000)057<2625:AMOSSE>2.0.CO;2

García-Gómez, H., Garrido, J. L., Vivanco, M. G., Lassaletta, L., Rábago, I., Àvila, A., Tsyro, S., Sánchez, G., Ortiz, A. G., González-Fernández, I. \& Alonso, R. (2014). Nitrogen deposition in Spain: modeled patterns and threatened habitats within the Natura 2000 network. Science of the Total Environment 485, 450-460. https://doi.org/10.1016/j.scitotenv.2014.03.112

García-Gómez, H., Izquieta-Rojano, S., Aguillaume, L., González-Fernández, I., Valiño, F., Elustondo, D., Santamaría, J. M., Àvila, A., Bytnerowicz, A., Bermejo, V. \& Alonso, R. (2018). Joining empirical and modelling approaches to estimate dry deposition of nitrogen in Mediterranean forests. Environmental Pollution 243, 427-436. https://doi.org/10.1016/j.envpol.2018.09.015

Gauss, M., Nyíri, Á., Benedictow, A. \& Klein, H. (2016a). Transboundary air pollution by main pollutants (S, N, O3) and PM in 2014, Portugal. Norwegian Meteorological Institute.

Gauss, M., Nyíri, Á., Benedictow, A. \& Klein, H. (2016b). Transboundary air pollution by main pollutants (S, N, O3) and PM in 2014, Spain. Norwegian Meteorological Institute. 
916 Gauss, M., Tsyro, S., Fagerli, H., Hjellbrekke, A.-G.; Aas, W. \& Solberg, S. (2017).

917 EMEP MSC-W model performance for acidifying and eutrophying components, photo-

918 oxidants and particulate matter in 2015. Supplementary material to EMEP Status Report

919 1/2017. Norwegian Meteorological Institute.

920 Greaver, T. L., Sullivan, T. J., Herrick, J. D., Barber, M. C., Baron, J. S., Cosby, B. J.,

921 Deerhake, M. E., Dennis, R. L., Dubois, J.-J. B., Goodale, C. L., Herlihy. A. T.,

922 Lawrence, G. B., Liu, L., Lynch, J. A. \& Novak, K. J. (2012). Ecological effects of

923 nitrogen and sulfur air pollution in the US: what do we know? Frontiers in Ecology and

924 the Environment 10(7), 365-372. https://doi.org/10.1890/110049

925 Hanna, S. R. \& Chang, J. (2010). Setting Acceptance Criteria for Air Quality Models.

926 Proceedings of the International Technical Meeting on Air Pollution Modelling and its

927 Application. Turin, Italy.

928 Henrard, M. \& Forti, R. (2016). Agriculture, forestry and fishery statistics. Eurostat.

929 https://doi.org/10.2785/147560

930 Hertel, O., Reis, S., Skjøth, C.A., Bleeker, A., Harrison, R., Cape, J. N., Fowler, D.,

931 Skiba, U., Simpson, D., Jickells, T., Baker, A., Kulmala, M., Gyldenkærne, S.,

932 Sørensen, L.L. \& Erisman, J. W. (2011). Nitrogen processes in the atmosphere. In Mark

933 A. Sutton, Clare M. Howard, Jan Willem Erisman, Gilles Billen, Albert Bleeker,

934 Peringe Grennfelt, Hans van Grinsven and Bruna Grizzetti (Eds): The European

935 Nitrogen Assessment. Cambridge University Press.

936 Hijmans, R.J. (2017). raster: Geographic Data Analysis and Modeling. R package

937 version 2.6-7. https://CRAN.R-project.org/package=raster

938 Im, U. Christodoulaki, S., Violaki, K., Zarmpas, P., Kocak, M., Daskalakis, N.,

939 Mihalopoulos, N. \& Kanakidou, M. (2013). Atmospheric deposition of nitrogen and

940 sulfur over southern Europe with focus on the Mediterranean and the Black Sea,

941 Atmospheric Environment 81, 660-670. https://doi.org/10.1016/j.atmosenv.2013.09.048

942 Instituto Português do Mar e da Atmosfera (2017). Total annual precipitation for

943 mainland Portugal, spatial interpolation from national climate stations.

944 IPCC 2006 (2006). IPCC Guidelines for National Greenhouse Gas Inventories,

945 Prepared by the National Greenhouse Gas Inventories Programme, Eggleston H.S.,

946 Buendia L., Miwa K., Ngara T. \& Tanabe K. (eds). Published: IGES, Japan.

947 Jia, Y., Yu, G., Gao, Y., He, N., Wang, Q., Jiao, C. \& Zuo, Y. (2016). Global inorganic

948 nitrogen dry deposition inferred from ground- and space-based measurements. Scientific

949 Reports 6, 19810. https://doi.org/10.1038/srep19810

950 Kryza, M., Dore, A.J., Błás, M. \& Sobik, M. (2009). Application of a Lagrangian

951 Model FRAME to Estimate Reduced Nitrogen Deposition and Ammonia

952 Concentrations in Poland. In: Sutton M.A., Reis S., Baker S.M. (Eds) Atmospheric

953 Ammonia. Springer, Dordrecht https://doi.org/10.1007/978-1-4020-9121-6_20.

954 Kryza, M., Blás, M., Dore, A.J. \& Sonik, M. (2010). National scale modelling of the

955 concentration and deposition of reduced nitrogen and its application to Poland.

956 Ecological Chemistry and Engineering S 17 (2): 161-176. 
Kryza, M., Mill, W., Dore, A. J., Werner, M., \& Błaś, M. (2013). Calculation of sulphur and nitrogen deposition with the frame model and assessment of the exceedance of critical loads in Poland. Ecological Chemistry and Engineering S 20(2), 279-290. https://doi.org/10.2478/eces-2013-0020

Levy, P., van Dijk, N., Gray, A., Sutton, M., Jones, M., Leeson, S., Dise, I., Leith, I. \& Sheppard, L. (2018). Response of a peat bog vegetation community to long- term experimental addition of nitrogen. Journal of Ecology. 107(3), 1167-1186. https://doi.org/10.1111/1365-2745.13107

Li, Y., Thompson, T. M., Van Damme, M., Chen, X., Benedict, K. B., Shao, Y., Day, D., Boris, A., Sullivan, A. P., Ham, J., Whitburn, S., Clarisse, L., Coheur, P.-F., \& Collett Jr., J. L. (2017). Temporal and spatial variability of ammonia in urban and agricultural regions of northern Colorado, United States, Atmospheric Chemistry and Physics 17, 6197-6213. https://doi.org/10.5194/acp-17-6197-2017

Lickley, M., \& Solomon, S. (2018). Drivers, timing and some impacts of global aridity change. Environmental Research Letters 13(10), 104010. https://doi.org/10.1088/17489326/aae013

Lorente- Plazas, R., Montávez, J. P., Jimenez, P. A., Jerez, S., Gómez- Navarro, J. J., García- Valero, J. A., \& Jimenez- Guerrero, P. (2015). Characterization of surface winds over the Iberian Peninsula. International Journal of Climatology, 35(6), 10071026. https://doi.org/10.1002/joc.4034

[dataset] Met Office (2012). Met Office Integrated Data Archive System (MIDAS) Land and Marine Surface Stations Data (1853-current). NCAS British Atmospheric Data Centre, 20/10/2019. http://catalogue.ceda.ac.uk/uuid/220a65615218d5c9cc9e4785a3234bd0

Monteiro, A., Ferreira, J., Ribeiro, I., Fernandes, A. P., Martins, H., Gama, C., \& Miranda, A. I. (2015). Air quality over Portugal in 2020. Atmospheric Pollution Research 6(5), 788-796. https://doi.org/10.5094/APR.2015.087

Morán, M., Ferreira, J., Martins, H., Monteiro, A., Borrego, C., \& González, J. A. (2016). Ammonia agriculture emissions: From EMEP to a high resolution inventory. Atmospheric Pollution Research 7(5), 786-798. https://doi.org/10.1016/j.apr.2016.04.001

[dataset] National Centers for Environmental Prediction/National Weather Service/NOAA/U.S. Department of Commerce (2000). NCEP FNL Operational Model Global Tropospheric Analyses, continuing from July 1999, Research Data Archive at the National Center for Atmospheric Research, Computational and Information Systems Laboratory, Boulder, Colo. (Updated daily.). https://doi.org/10.5065/D6M043C6

Ninyerola M., Pons, X. \& Roure, J. M. (2005). Atlas Climático Digital de la Península Ibérica. Metodología y Aplicaciones en Bioclimatología y Geobotánica. Universidad Autónoma de Barcelona: Bellaterra.

[dataset] Norwegian Institute for Air Research, EBAS database, Available at http://ebas.nilu.no/, Accessed 29-12-2017. 
998 Nowak, D., Jovan, S., Branquinho, C., Augusto, S., Ribeiro, M. C. \& Kretsch, C. E. 999 (2015). Chapter 4: Biodiversity, air quality and human health. In: Romanelli, C.,

1000 Cooper, D., Campbell-Lendrum, D., Maiero, M., Karesh, W.B., Hunter, D. \& Golden, 1001 C.D. (Eds), Connecting Global Priorities - Biodiversity and Human Health: A State of 1002 Knowledge Review. World Health Organization and Secretariat of the Convention on 1003 Biological Diversity, 63-74.

1004 OECD (2012). Redefining "Urban": A New Way to Measure Metropolitan Areas, 1005 OECD Publishing. https://doi.org/10.1787/9789264174108-en

1006 [dataset] OECD, Delimitation of functional urban areas by country, Available at 1007 https://www.oecd.org/cfe/regional-policy/functionalurbanareasbycountry.htm, Accessed 1008 04-09-2019.

1009 [dataset] Oliveira, M.A., Tomilson, S.J., Carnell, E.J., Dore, A.J., Serrano, H.C., Vieno, 1010 M., Cordovil, C.M.d.S., Dragosits, U., Sutton, M.A., Branquinho, C. \& Pinho, P. 1011 (2019). Maps of modeled concentration of Nitrogen and Sulfur components and 1012 Nitrogen deposition in the W Iberian Peninsula. Mendeley Data, v1.

1013 https://doi.org/10.17632/9482zcmdfb.1

1014 Palmieri, A., Dominici, P., Kasanko, M. \& Martino, L. (2011). Diversified landscape 1015 structure in the EU Member States. Eurostats.

1016 Pan, Y.P., Wang, Y.S., Tang, G.Q. \& Wu, D. (2013). Spatial distribution and temporal 1017 variations of atmospheric sulfur deposition in Northern China: insights into the potential 1018 acidification risks. Atmospheric Chemistry and Physics 13, 1678-1688.

1019 https://doi.org/10.5194/acp-13-1675-2013

1020 Pinho, P., Dias, T., Cruz, C., Sim Tang, Y., Sutton, M. A., Martins- Loução, M., 1021 Máguas, C. \& Branquinho, C. (2011). Using lichen functional diversity to assess the 1022 effects of atmospheric ammonia in Mediterranean woodlands. Journal of Applied 1023 Ecology, 48, 1107-1116. https://doi.org/10.1111/j.1365-2664.2011.02033.x

1024 Pinho, P., Dias, T., Cordovil, C.M.d.S., Dragosits, U., Dise, N. B., Sutton, M. A. \& 1025 Branquinho, C. (2018). Mapping Portuguese Natura 2000 sites in risk of biodiversity 1026 change caused by atmospheric nitrogen pollution. PLoS ONE 13(6). e0198955. 1027 https://doi.org/10.1371/journal.pone.0198955

1028 R Core Team (2017). R: A language and environment for statistical computing. R. 1029 Foundation for Statistical Computing, Vienna, Austria. URL https://www.R-project.org/

1030 Reis, S., Grennfelt, P., Klimont, Z., Amann, M., ApSimon, H., Hettelingh, J.-P., 1031 Holland, M., LeGall, A.-C., Maas, R., Posch, M., Spranger, T., Sutton, M. A. \& 1032 Williams, M. (2012). From acid rain to climate change. Science 338(6111), 1153-1154. 1033 https://doi.org/10.1126/science.1226514

1034 Simpson, D., Benedictow, A., Berge, H., Bergström, R., Emberson, L. D., Fagerli, H., 1035 Flechard, C. R., Hayman, G. D., Gauss, M., Jonson, J. E., Jenkin, M. E., Nyíri, A., 1036 Richter, C., Semeena, V. S., Tsyro, S., Tuovinen, J.-P., Valdebenito, Á., \& Wind, P. 1037 (2012). The EMEP MSC-W chemical transport model - technical description, 1038 Atmospheric Chemistry and Physics 12, 7825-7865. https://doi.org/10.5194/acp-12$1039 \quad 7825-2012$ 
1040 Simpson, D., Bergström, R., Imhof, H. \& Wind, P. (2017). Updates to the EMEP MSC1041 W model, 2016-2017, Transboundary particulate matter, photo-oxidants, acidifying and 1042 eutrophying components. Status Report 1/2017, The Norwegian Meteorological 1043 Institute, Norway, 115-122.

1044 Simpson, D., Wind, P., Bergstrôm, R., Gauss, M., Tsyro, S. \& Valdebenito, A. (2018).

1045 Updates to the EMEP MSC-W model, 2017-2018, 2017-2019 Transboundary

1046 particulate matter, photo-oxidants, acidifying and eutrophying components. Status

1047 Report 1/2018, The Norwegian Meteorological Institute, Norway, 109-116.

1048 Singles, R., Sutton, M. A., \& Weston, K. J. (1998). A multi-layer model to describe the 1049 atmospheric transport and deposition of ammonia in Great Britain. Atmospheric 1050 Environment 32(3), 393-399. https://doi.org/10.1016/S1352-2310(97)83467-X

1051 Skamarock, W. C., Klemp, J. B., Dudhia, J, Gill, D. O, Barker, D. M., Duda, M. G., 1052 Huang, X.-Y, Wang, W. \& Powers, J. G. (2008). A Description of the Advanced 1053 Research WRF Version 3. NCAR Technical Note NCAR/TN-475+STR, 1054 https://doi.org/10.5065/D68S4MVH.

1055 Skjøth, C. \& Geels, C. (2013). The effect of climate and climate change on ammonia 1056 emissions in Europe. Atmospheric Chemistry and Physics 13, 117-128.

1057 https://doi.org/10.5194/acp-13-117-2013

1058 Smith, R. I., Fowler, D., Sutton, M. A., Flechard, C. \& Coyle, M. (2000). Regional 1059 estimation of pollutant gas dry deposition in the UK: model description, sensitivity 1060 analyses and outputs. Atmospheric Environment 34(22), 3757-3777.

1061 https://doi.org/10.1016/S1352-2310(99)00517-8

1062 Sutton, M. A., Milford, C., Dragosits, U., Place, C. J., Singles, R. J., Smith, R. I., 1063 Pitcairn, C. E. R., Fowler, D., Hill, J., ApSimon, H. M., Ross, C., Hill, R., Jarvis, S. C., 1064 Pain, B. F., Phillips, V. C., Harrison, R., Moss, D., Webb, J., Espenhahn, S.E., Lee, 1065 D.S., Hornung, M., Ullyett, J., Bull, K.R., Emmett, B.A., Lowe, J. \& Wyers, G.P. 1066 (1998). Dispersion, deposition and impacts of atmospheric ammonia: quantifying local 1067 budgets and spatial variability. Environmental Pollution 102, 349-361.

1068 https://doi.org/10.1016/S0269-7491(98)80054-7

1069 [dataset] The European Pollutant Release and Transfer Register (E-PRTR), Member 1070 States reporting under Article 7 of Regulation (EC) No 166/2006. Available at 1071 https://www.eea.europa.eu/ds_resolveuid/d713ba1cc9374b9a95eea07531f62e6c 1072 Accessed 29-09-2018.

1073 [dataset] The Norwegian Meteorological Institute, EMEP MSC-W modelled air 1074 concentrations and depositions. Available at 1075 https://www.emep.int/mscw/mscw_moddata.html, Accessed 13-04-2018.

1076 Tsyro, S., As, W., Solberg, S., Benedictow, A., Fagerli, H. \& Posh, M. (2018). Status of 1077 transboundary air pollution in 2016, 2017-2019 Transboundary particulate matter, 1078 photo-oxidants, acidifying and eutrophying components. Status Report 1/2018, The 1079 Norwegian Meteorological Institute, Norway, 15-40. 
1080 United Nations. (2015). A/RES/70/1 - transforming our world: the 2030 Agenda for

1081 Sustainable Development. Resolution adopted by the General Assembly on 25

1082 September 2015.

1083 Urbanek, S. (2012). proj4: A simple interface to the PROJ.4 cartographic projections

1084 library. R package version 1.0-8. https://CRAN.R-project.org/package=proj4

1085 van Pul, A., Hertel, O., Geels, C., Dore, J., Vieno, M., van Jaarsveld, H.A., Bergström,

1086 R., Shaap, M. \& Fagerli, H. (2009a). Modelling of the Atmospheric Transport and

1087 Deposition of Ammonia at a National and Regional Scale. In: Sutton, M.A., Reis, S. \&

1088 Baker, S.M.H. (Eds): Atmospheric Ammonia-Detecting emission changes and

1089 environmental impacts. Springer.

1090 van Pul, A., Reis, S., Dore, T., Xuejun, L., Gaferli, H., Geels, C., Hertel, O., Kruijt,

1091 R.W., Kryza, M., Bergström, R., Vieno, M., Smith, R. \& Nemitz, E. (2009b). Modelling

1092 the National and Regional Transport and Deposition of Ammonia. In: Sutton, M.A.,

1093 Reis, S. \& Baker, S.M.H. (Eds): Atmospheric Ammonia-Detecting emission changes

1094 and environmental impacts. Springer

1095 Vieno, M. (2006). The use of an Atmospheric Chemistry-Transport Model (FRAME)

1096 over the UK and the development of its numerical and physical schemes. PhD Thesis.

1097 The University of Edinburgh.

1098 Vieno, M., Dore, A. J., Bealey, W. J., Stevenson, D. S. \& Sutton, M. A. (2010). The

1099 importance of source configuration in quantifying footprints of regional atmospheric

1100 sulphur deposition. Science of the Total Environment 408, 985-995.

1101 https://doi.org/10.1016/j.scitotenv.2009.10.048

1102 Vieno, M., Heal, M. R., Hallsworth, S., Famulari, D., Doherty, R. M., Dore, A. J., Tang,

1103 Y. S., Braban, C. F., Leaver, D., Sutton, M. A., and Reis, S.(2014). The role of long-

1104 range transport and domestic emissions in determining atmospheric secondary inorganic

1105 particle concentrations across the UK. Atmospheric Chemistry and Physics 14, 8435-

1106 8447. https://doi.org/10.5194/acp-14-8435-2014

1107 Vieno, M., Heal, M. R., Williams, M. L., Carnell, E. J., Nemitz, E., Stedman, J. R., \&

1108 Reis, S. (2016). The sensitivities of emissions reductions for the mitigation of UK

1109 PM2.5, Atmospheric Chemistry and Physics 16, 265-276. https://doi.org/10.5194/acp-

$1110 \quad 16-265-2016$

1111 Vogt, E., Dragosits, U., Braban, C.F., Theobald, M. R., Dore, A. J., van Dijk, N., Tang,

1112 Y. S., McDonald, C., Murray, S., Rees, R. M. \& Sutton, M. A. (2013). Heterogeneity of

1113 atmospheric ammonia at the landscape scale and consequences for environmental

1114 impact assessment. Environmental Pollution 179, 120-131.

1115 https://doi.org/10.1016/j.envpol.2013.04.014

1116 Winiwarter, W. \& Schimak, G. (2005). Environmental software systems for emission

1117 inventories. Environmental Modelling \& Software 20(12), 1469-1477.

1118 https://doi.org/10.1016/j.envsoft.2004.07.017

1119 Yates, T., Coote, A. \& Butlin, R. (1988). The effect of acid deposition on buildings and 1120 building materials. Construction and Building Materials 2(1), 20-26.

1121 https://doi.org/10.1016/0950-0618(88)90005-0 
1122 Zhang, Y., Dore, A. J., Liu, X. \& Zhang, F. (2011). Simulation of nitrogen deposition in 1123 the North China Plain by the FRAME model. Biogeosciences 8: 3319-3329.

1124 https://doi.org/10.5194/bg-8-3319-2011

1125 
Maria Alexandra Oliveira: Conceptualization, Methodology, Validation, Formal analysis, Investigation, Resources, Data Curation, Writing - Original Draf, Visualization. Sam J.

Tomlinson: Conceptualization, Methodology, Formal analysis, Investigation, Resources, Writing - Review \& Editing. Edward J. Carnell: Conceptualization, Methodology, Formal analysis, Investigation, Resources, Writing - Review \& Editing. Anthony J. Dore:

Conceptualization, Methodology, Software; Writing - Review \& Editing. Helena C. Serrano: Writing- Reviewing and Editing, Project administration. Massimo Vieno: Conceptualization, Methodology, Software; Validation, Resources, Writing - Review \& Editing, Visualization. Cláudia M.d.S. Cordovil: Writing- Reviewing and Editing, Funding acquisition. Ulrike Dragosits: Conceptualization, Methodology, Writing- Reviewing and Editing, Supervision. Mark A. Sutton: Writing - Review \& Editing. Cristina Branquinho: Conceptualization, Writing - Review \& Editing, Supervision, Project administration. Pedro Pinho: Conceptualization, Methodology, Writing - Original Draft, Writing - Review \& Editing, Supervision, Project administration. 

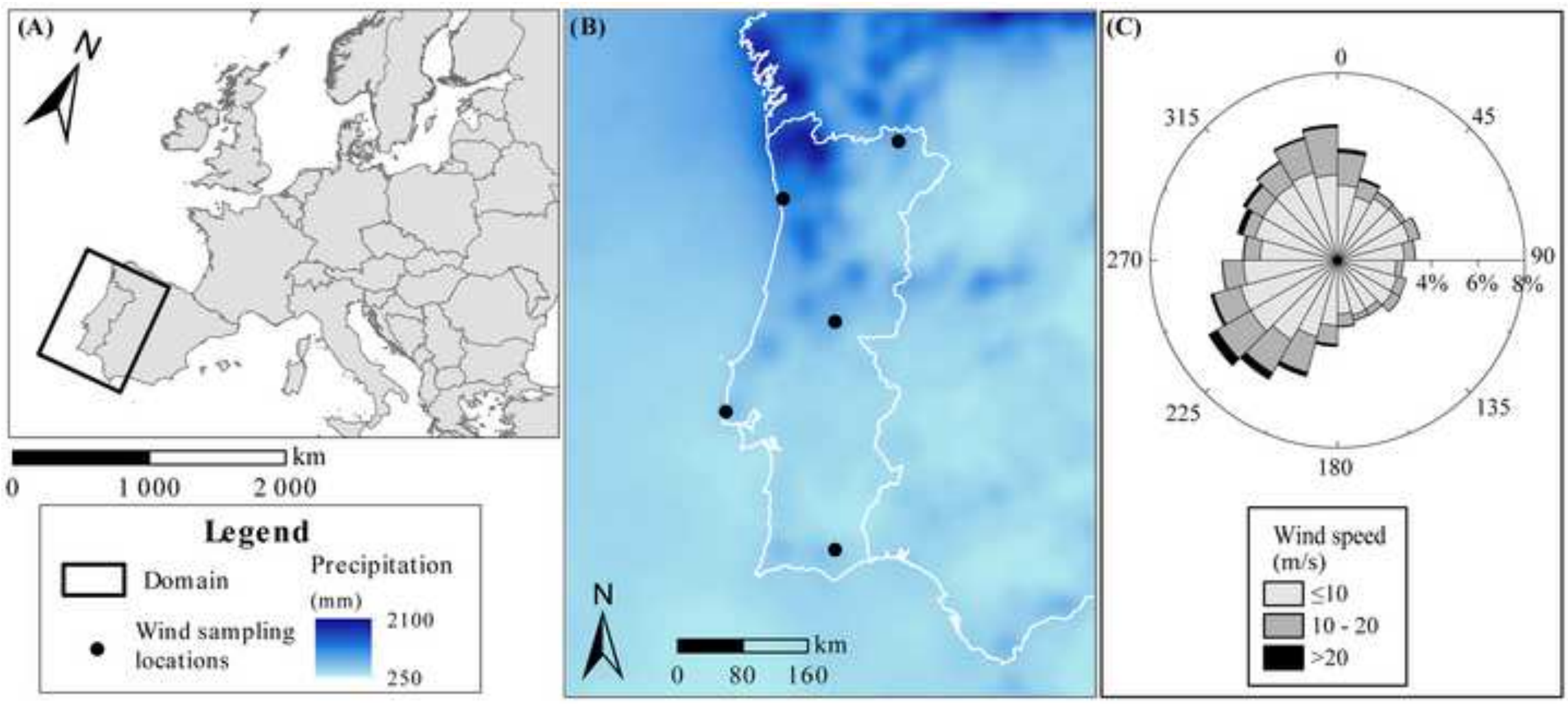


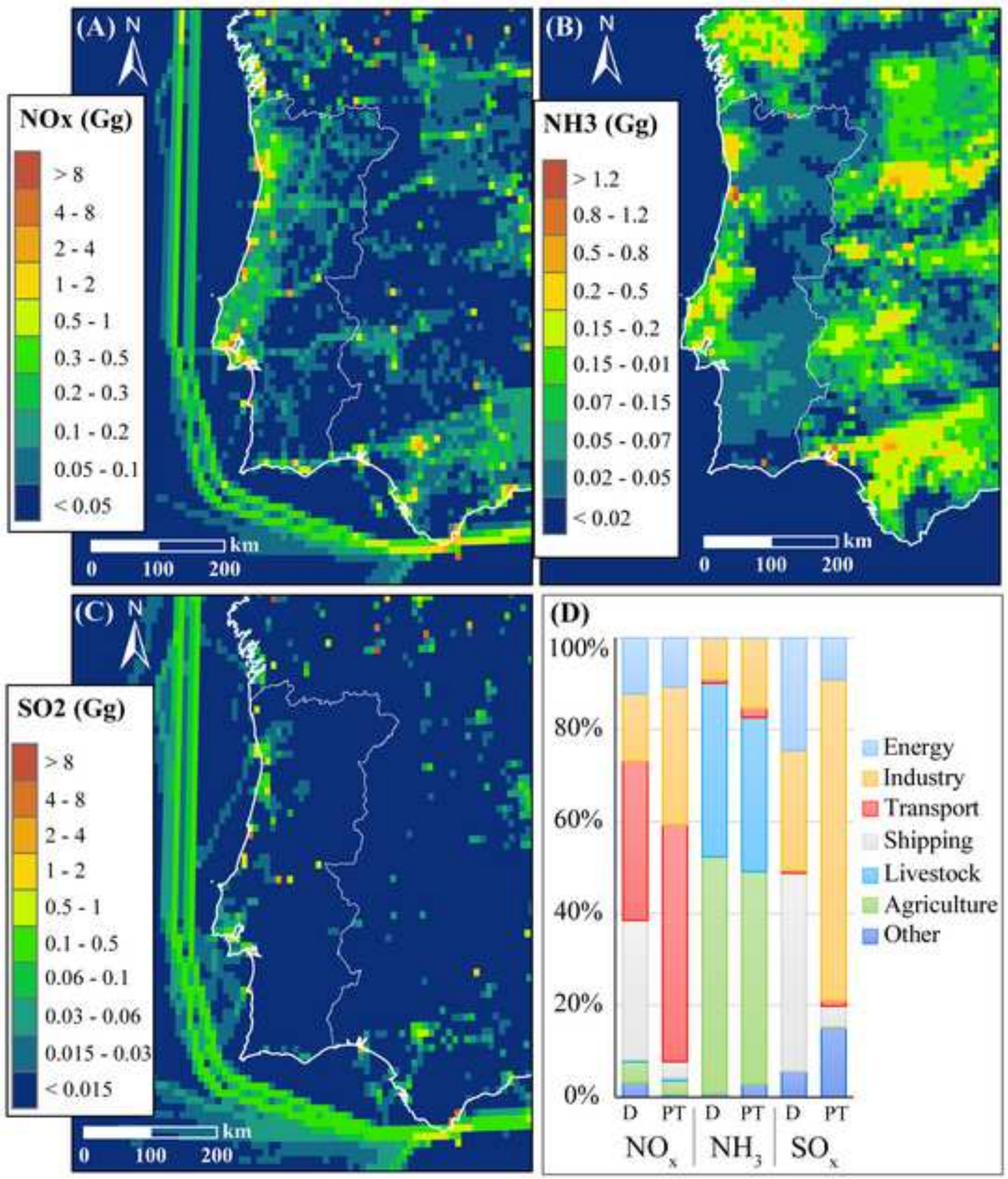




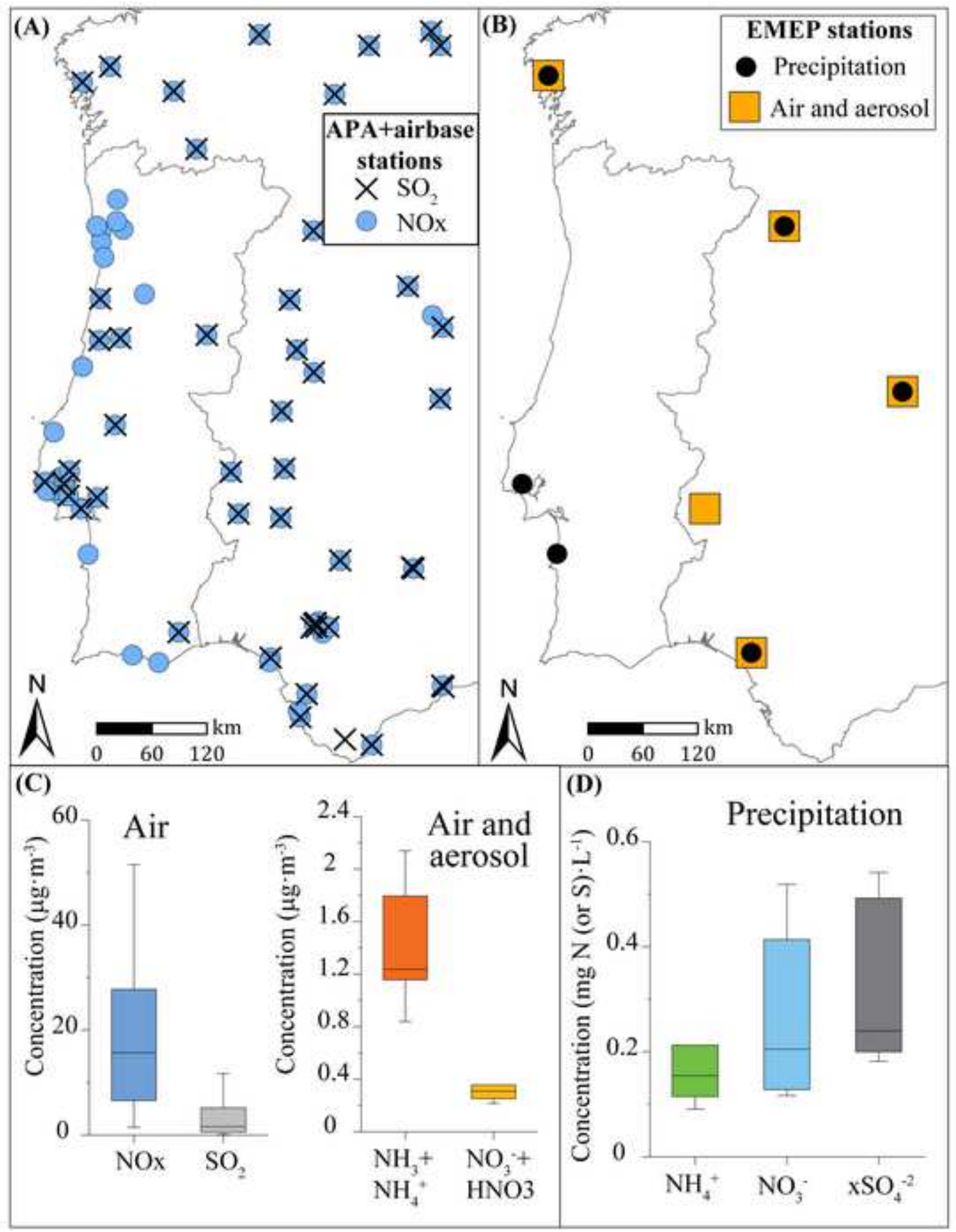




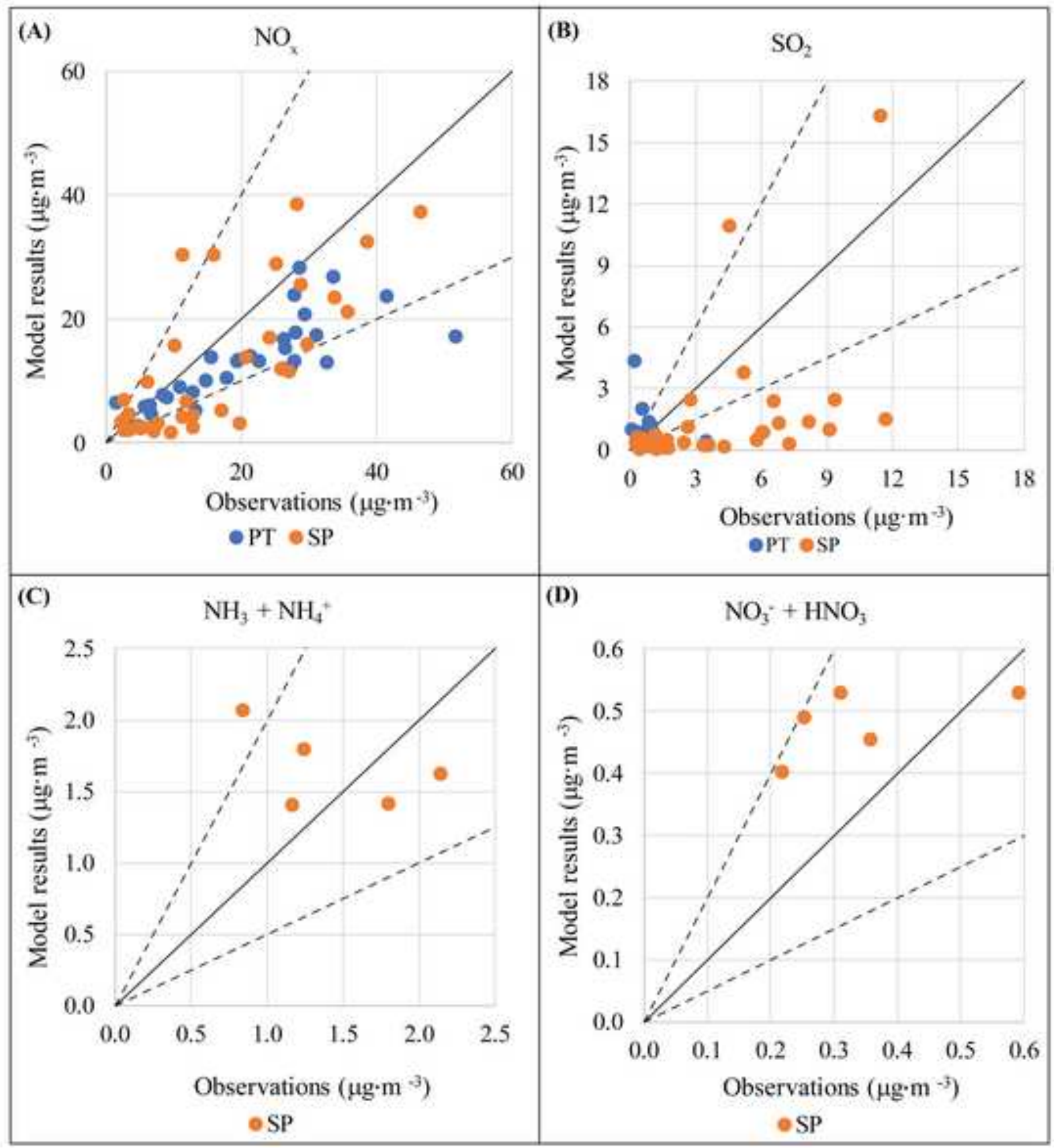


Color figure 5
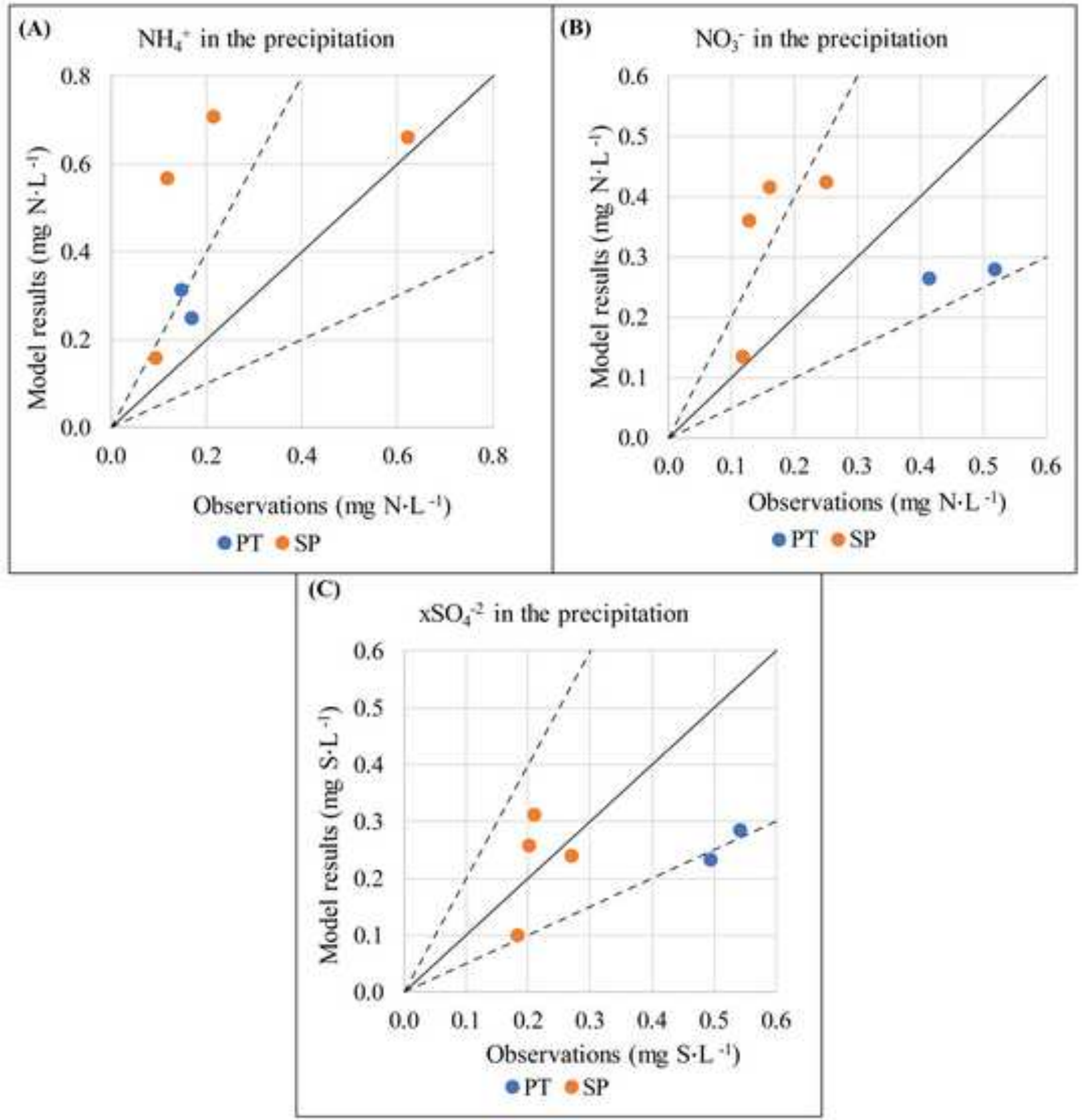

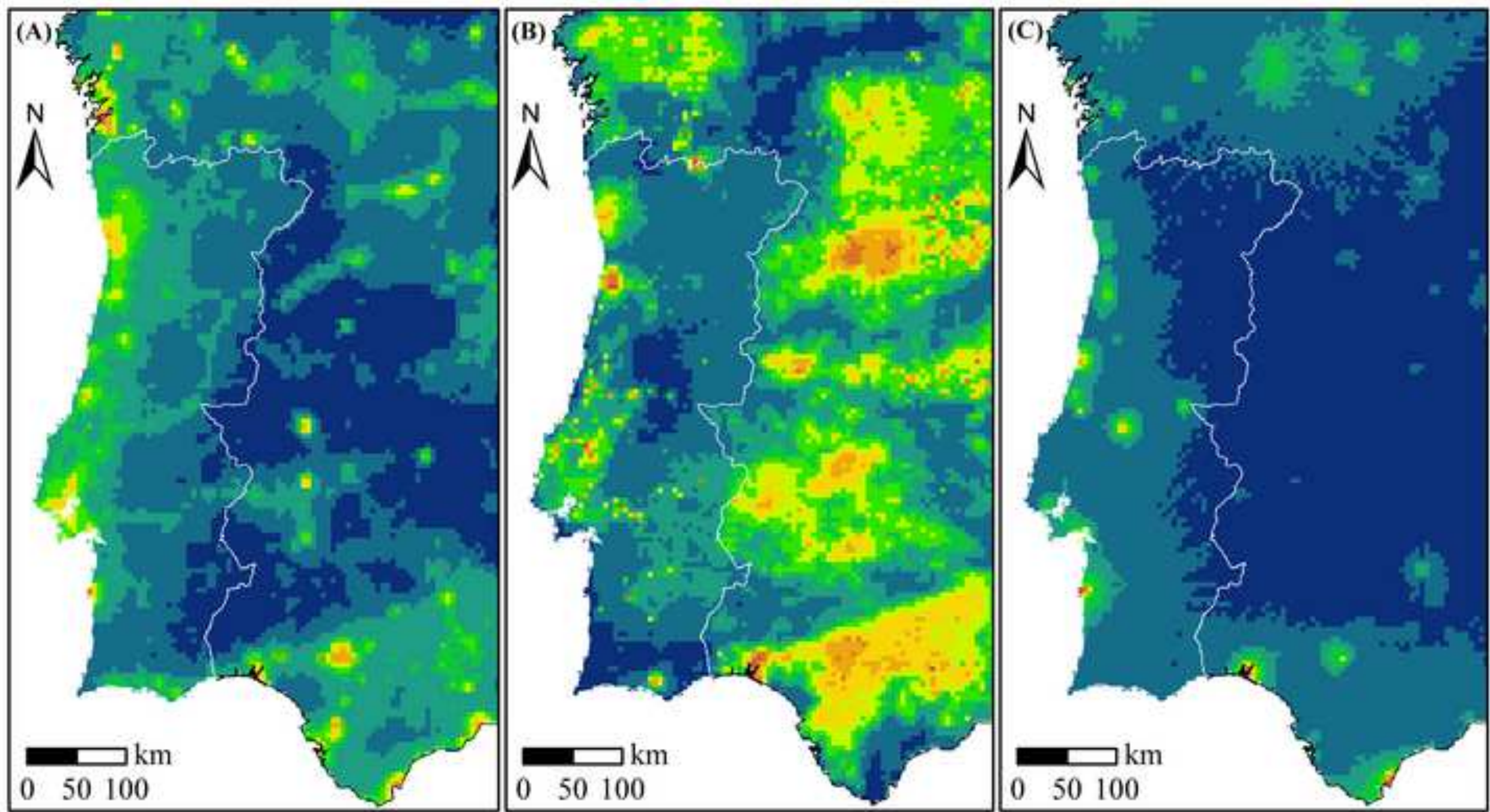

$\mathrm{NO}_{\mathbf{x}}\left(\mu \mathrm{g} \cdot \mathrm{m}^{-3}\right)$

$\mathrm{NH}_{3}\left(\mu \mathrm{g} \cdot \mathrm{m}^{-3}\right)$

$\mathrm{SO}_{2}\left(\mu \mathrm{g} \cdot \mathrm{m}^{-3}\right)$

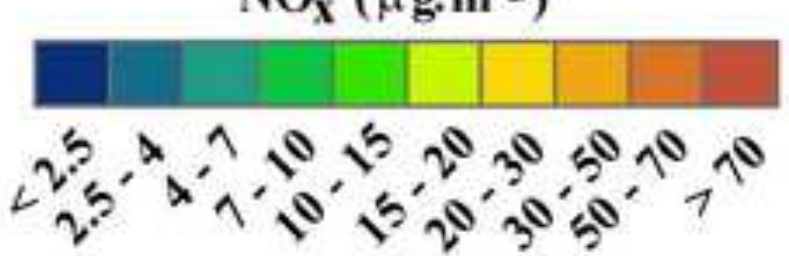

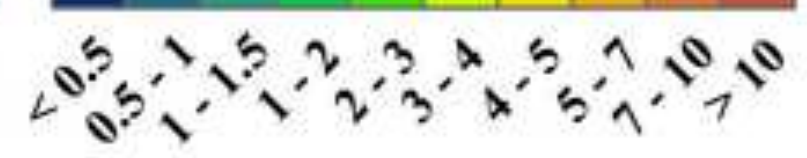

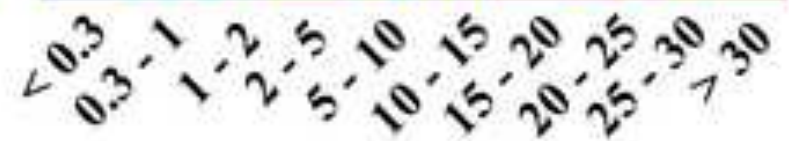




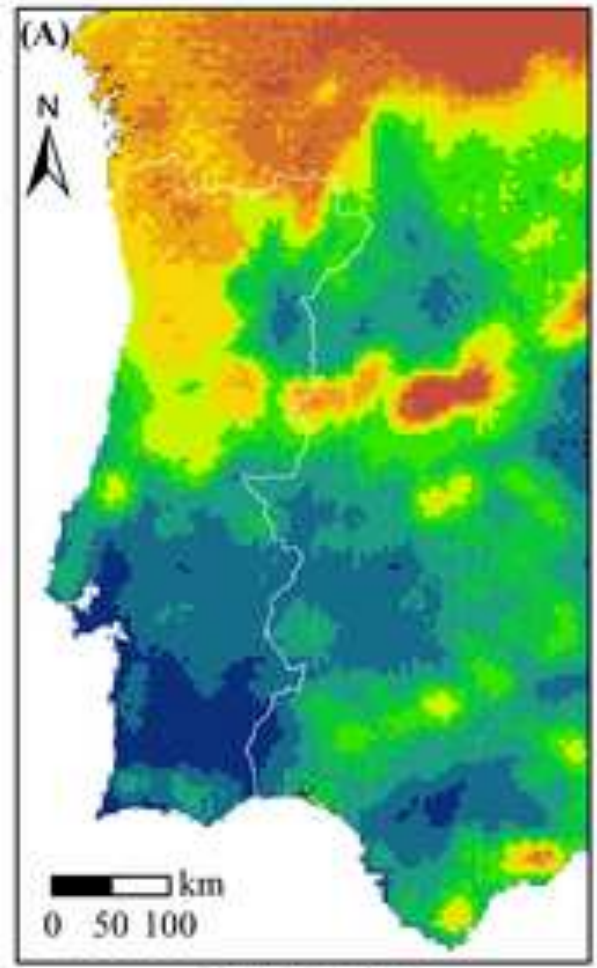

Wet deposition oxidized $\mathrm{N}\left(\mathrm{kg} \mathrm{N} \cdot \mathrm{ha}^{-1}\right)$
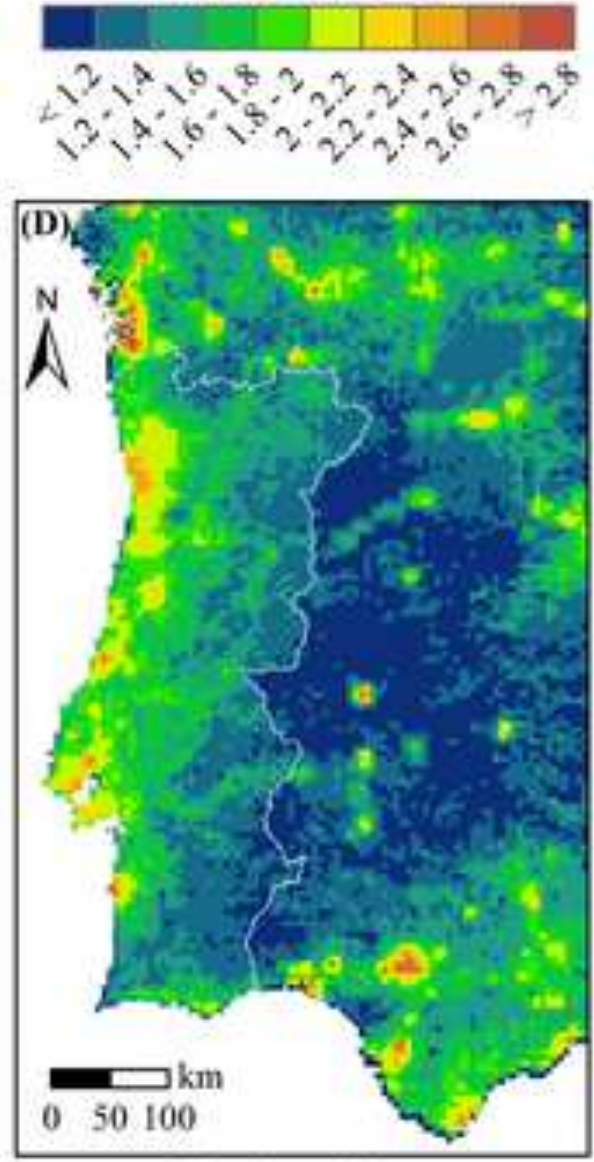

Dry deposition

oxidized $\mathrm{N}\left(\mathrm{kg} \mathrm{N} \cdot \mathrm{ha}^{-1}\right)$

$\Rightarrow 2 x^{2}+2 x^{2}+3^{2}+3^{3}+6$

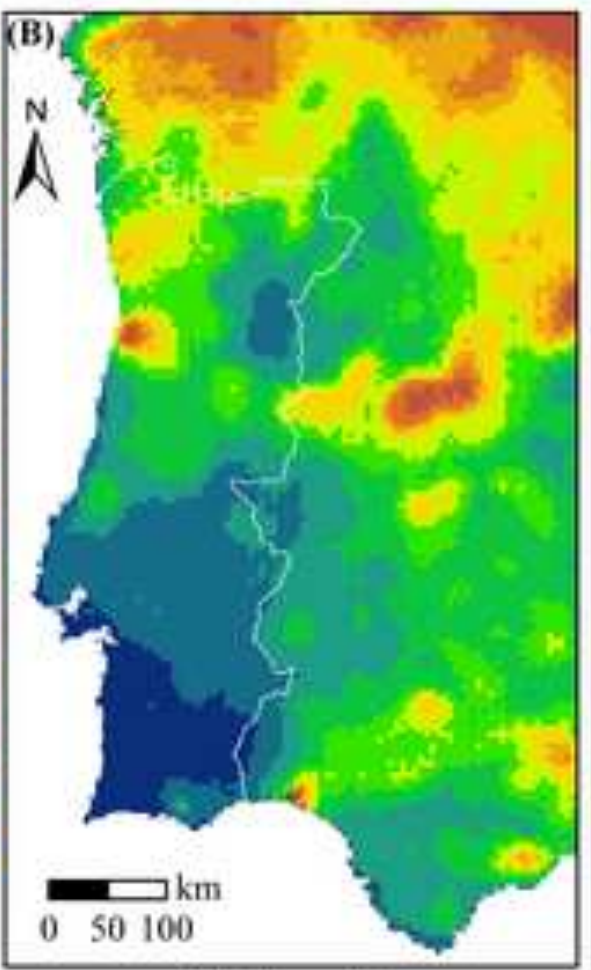

Wet deposition reduced $\mathrm{N}\left(\mathrm{kg} \mathrm{N} \cdot \mathrm{ha}^{-1}\right)$

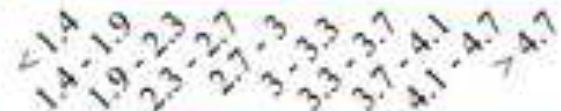

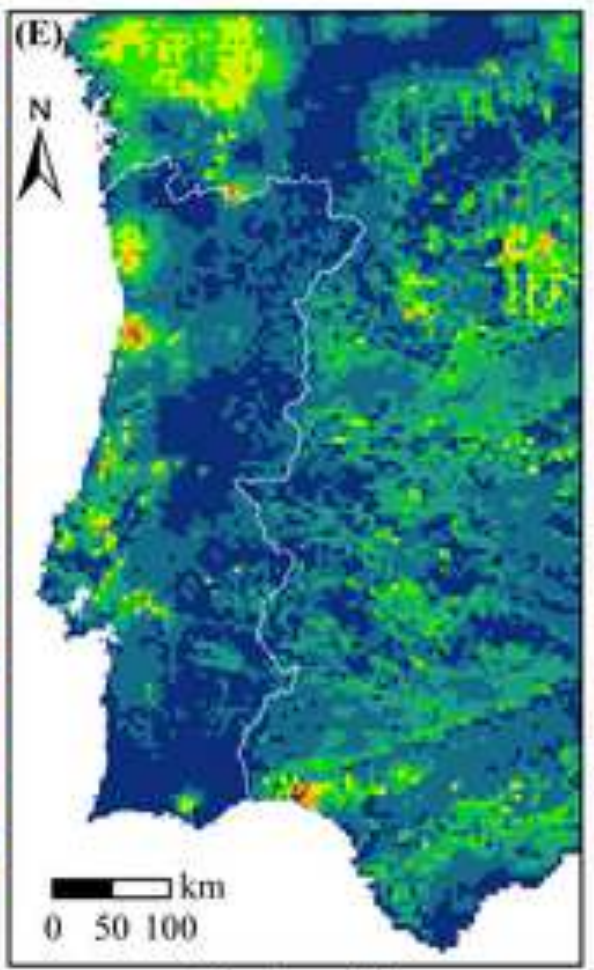

Dry deposition reduced N $\left(\mathrm{kg} \mathrm{N} \cdot \mathrm{ha}^{-1}\right)$

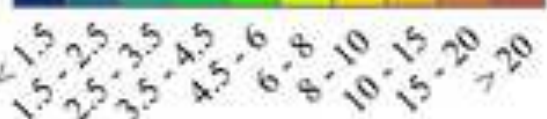

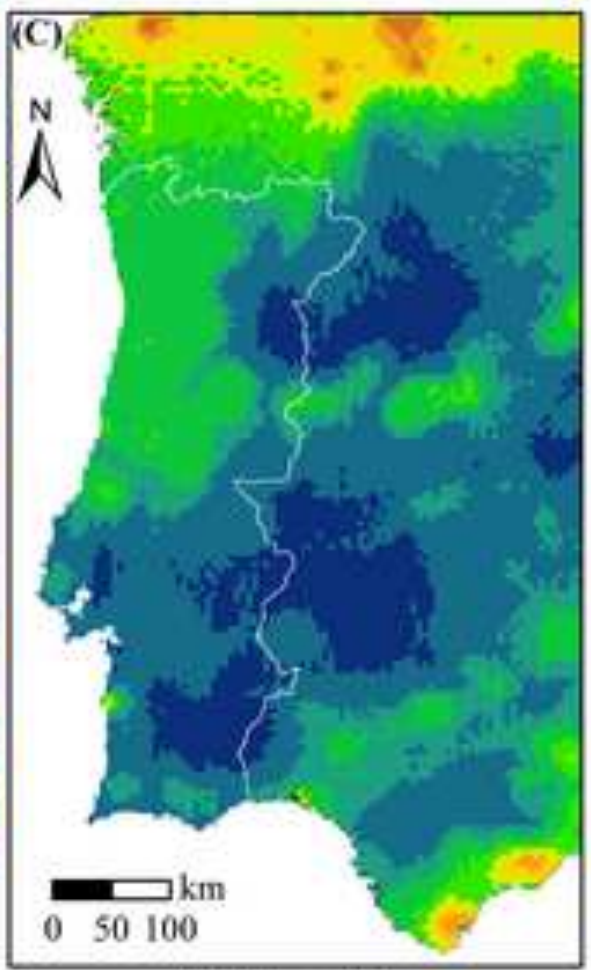

Wet deposition oxidized S (kg S- hat $\left.{ }^{-1}\right)$

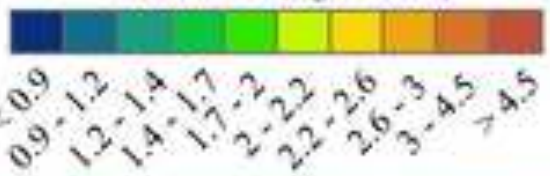

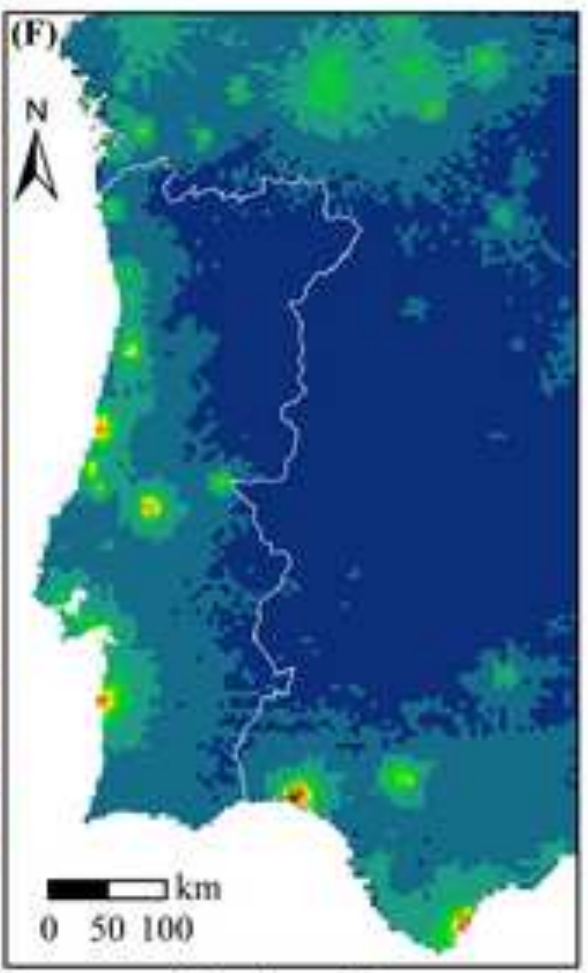

Dry deposition oxidized $S\left(\mathrm{~kg} \mathrm{~S} \cdot \mathrm{ha}^{-1}\right.$ )

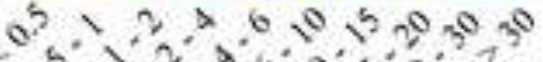


Total $\mathrm{N}$ deposition

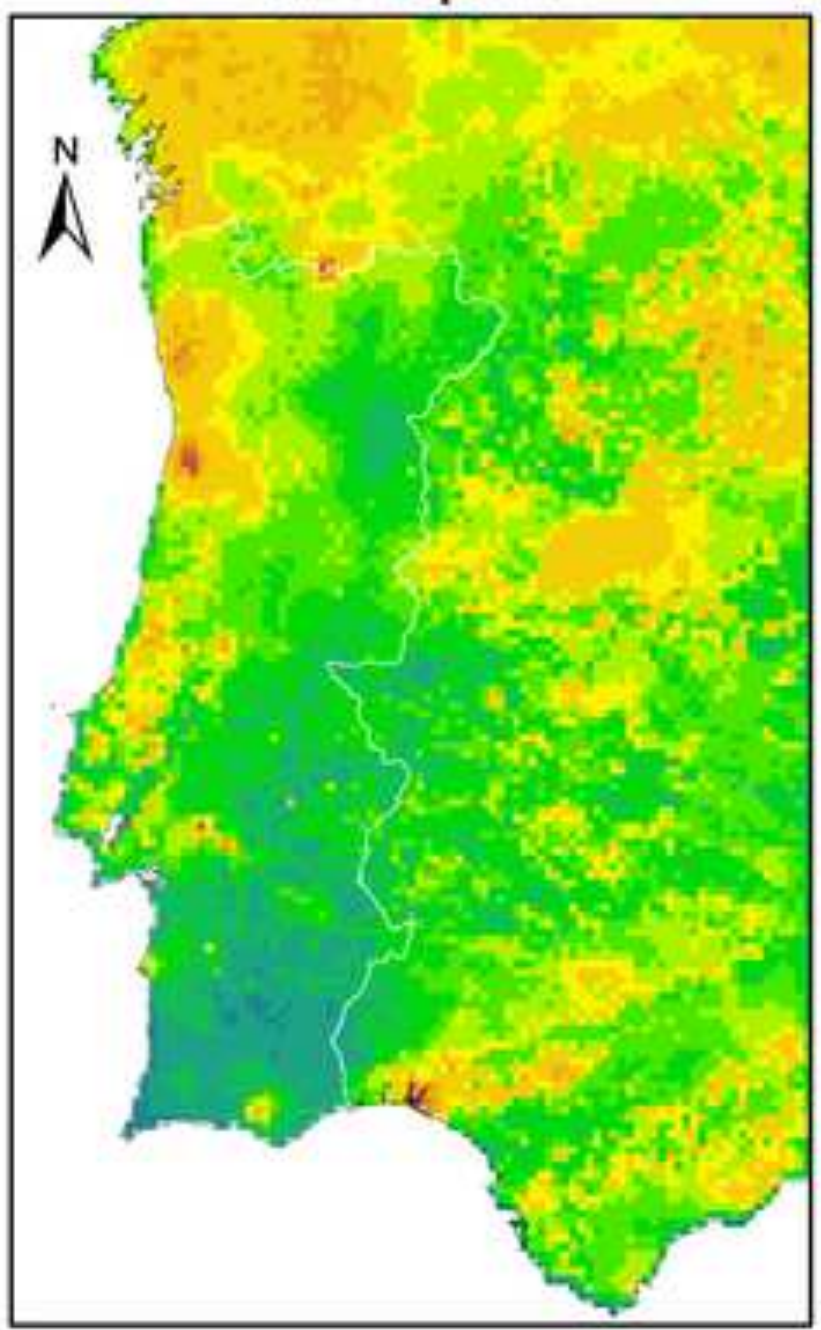

$\mathrm{N}$ and $\mathrm{S}$ deposition $\left(\mathrm{kg} \cdot \mathrm{ha}^{-1}\right)$

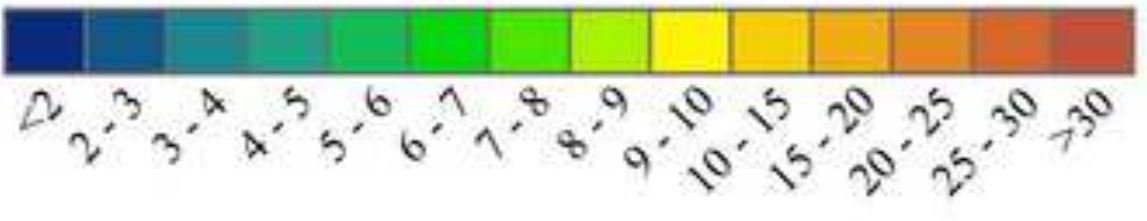

Total S deposition

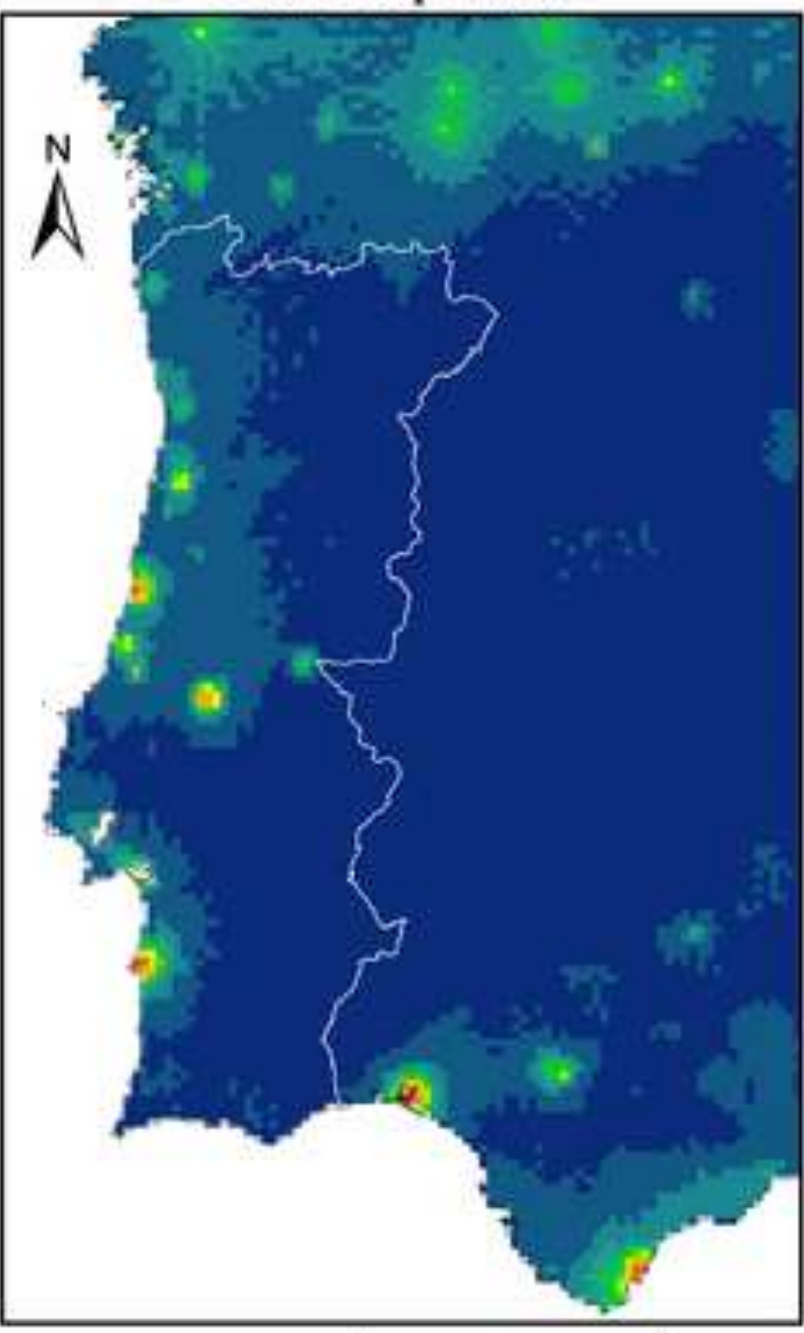

Functional urban areas

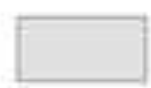

Urban and industrial regions

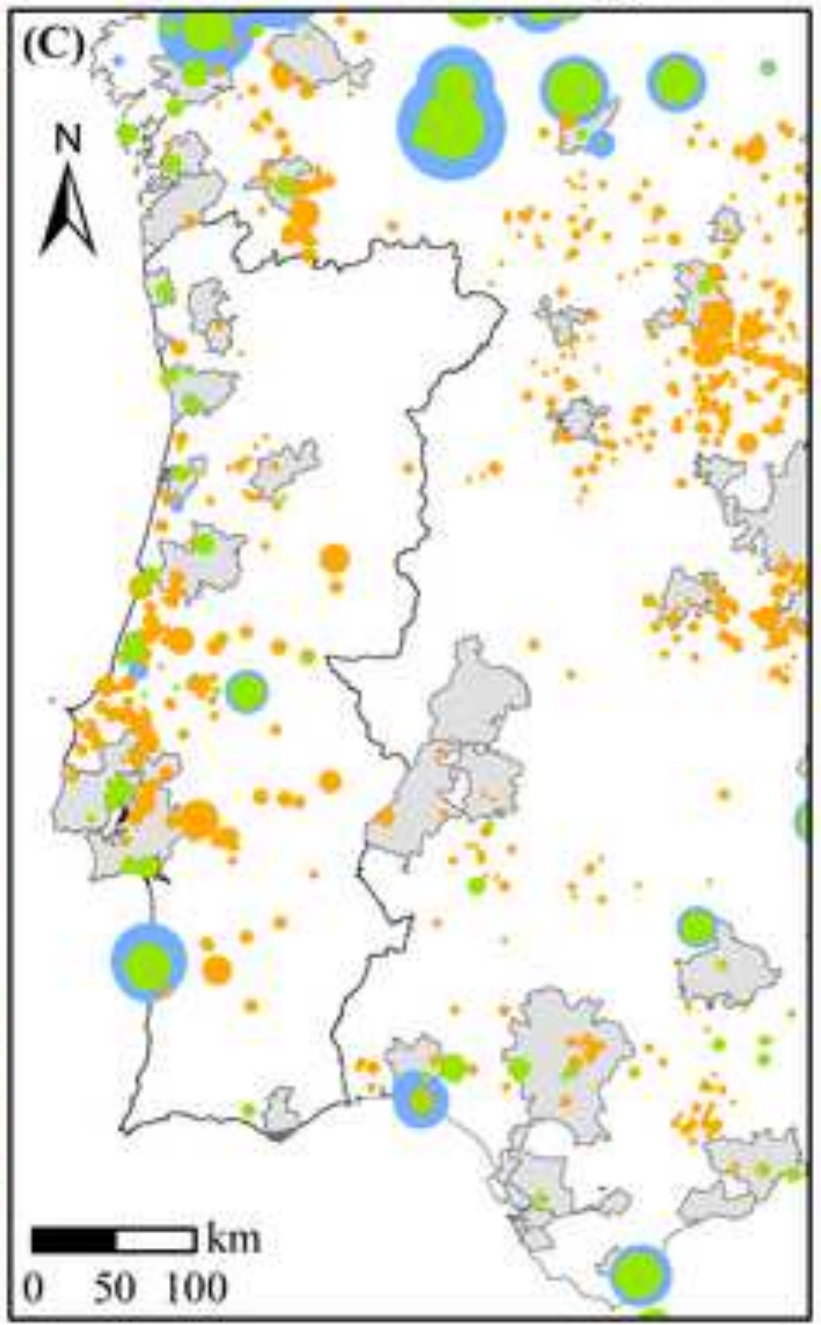

\section{LPS emissions (ton)}

$\mathrm{NH}_{3}$

SOx

100000

1000000

10000000
10000
100000
1000000

10000

- 100000

1000000 